University of Louisville

ThinkIR: The University of Louisville's Institutional Repository

Electronic Theses and Dissertations

8-2007

\title{
Charles Lang Freer and his gallery of art : turn-of-the-century politics and aesthetics on the National Mall.
}

Patricia L. Guardiola
University of Louisville

Follow this and additional works at: https://ir.library.louisville.edu/etd

\section{Recommended Citation}

Guardiola, Patricia L., "Charles Lang Freer and his gallery of art : turn-of-the-century politics and aesthetics on the National Mall." (2007). Electronic Theses and Dissertations. Paper 543.

https://doi.org/10.18297/etd/543

This Master's Thesis is brought to you for free and open access by ThinkIR: The University of Louisville's Institutional Repository. It has been accepted for inclusion in Electronic Theses and Dissertations by an authorized administrator of ThinkIR: The University of Louisville's Institutional Repository. This title appears here courtesy of the author, who has retained all other copyrights. For more information, please contact thinkir@louisville.edu. 
CHARLES LANG FREER AND HIS GALLERY OF ART: TURN-OF-THE-CENTURY POLITICS AND AESTHETICS ON THE NATIONAL MALL

\title{
By
}

Patricia L. Guardiola

B.A., Bellarmine University, 2004

\author{
A Thesis \\ Submitted to the Faculty of the \\ Graduate School of the University of Louisville \\ In Partial Fulfillment of the Requirements \\ For the Degree of
}

Master of Arts

Department of Fine Arts

University of Louisville

Louisville, Kentucky

August 2007 
CHARLES LANG FREER AND HIS GALLERY OF ART:

TURN-OF-THE-CENTURY POLITICS AND AESTHETICS ON THE NATIONAL MALL

By

Patricia L. Guardiola

B.A., Bellarmine University, 2004

A Thesis Approved on

June 8, 2007

By the following Thesis Committee:

Thesis Director 


\section{DEDICATION}

In memory of my grandfathers,

Mr. Leonard Bright

and

Dr. Salvador Guardiola. 


\section{ACKNOWLEDGEMENTS}

I would like to thank the members of my reading committee, Dr. Benjamin Hufbauer, Dr. Susan Jarosi, and Dr. John Ferré, for their patience and valuable commentary.

I could not have accomplished this project without my fellow Art History graduate students, whose advice and brilliant humor created a wonderful sense of community.

Finally, I thank my family for the financial stability and emotional security that have allowed me to come this far. 


\title{
ABSTRACT \\ CHARLES LANG FREER AND HIS GALLERY OF ART: \\ TURN-OF-THE-CENTURY POLITICS AND AESTHETICS \\ ON THE NATIONAL MALL
}

\author{
Patricia L. Guardiola
}

August 10, 2007

This qualifying paper examines the contradiction of a public museum dedicated to one man's vision of art collecting. Charles Lang Freer established the Freer Gallery of Art in 1906, regarded as the first national public art museum on the National Mall. Section One presents the biographical history of Freer, and clarifies his place in the contexts of collecting and aestheticism at the turn of the century. Section Two presents the political situation in Washington, D.C. that gave way to President Theodore Roosevelt's efforts to use Freer's private collection for a public museum on the National Mall. This paper concludes with a review of the original visitors' reactions at the museum's 1923 opening. The reactions of the first visitors are then connected to the present condition of the museum and its relevance today. 


\section{LIST OF FIGURES}

FIGURE

PAGE

1. J.A.M. Whistler, Caprice in Purple and Gold, No. 2: The Golden Screen, 1864_....41

2. J.A.M. Whistler, Nocturne in Blue and Silver: Cremorne Lights, $1872 \ldots \ldots \ldots \ldots \ldots 41$

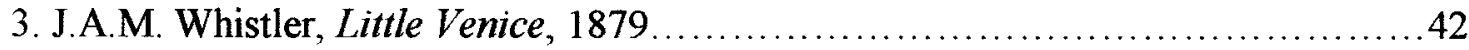

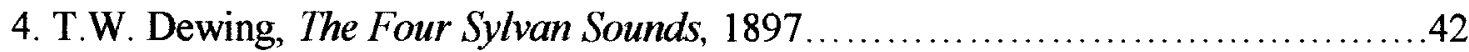

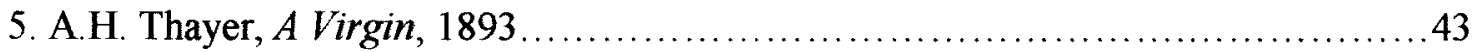

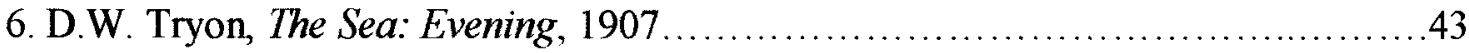

7. Freer comparing Whistler's Vemis Rising and glazed pot, $1909 \ldots \ldots \ldots \ldots \ldots \ldots \ldots 44$

8. Syrian jar, ca. $16^{\text {th }}$ century, Freer Gallery of Art ............................... 45

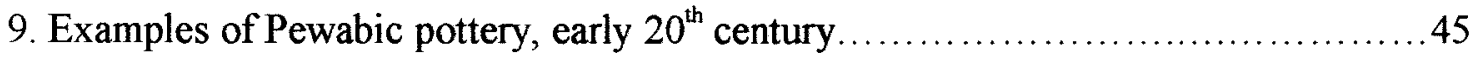

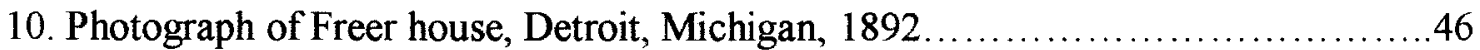

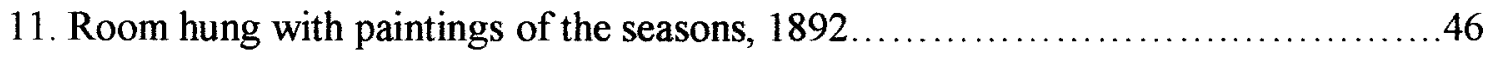

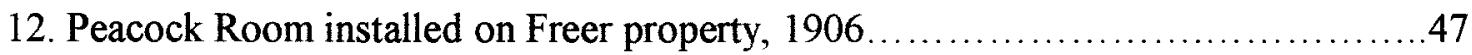

13. Gallery space, Freer house, 1904 expansion...............................47

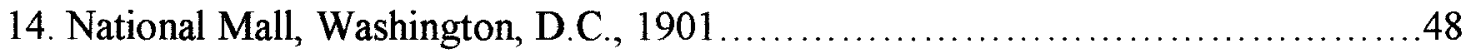

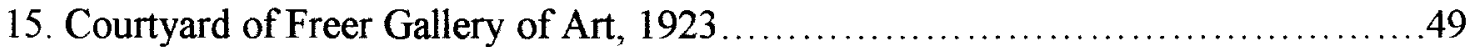

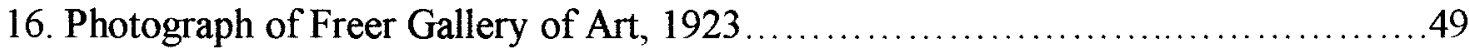

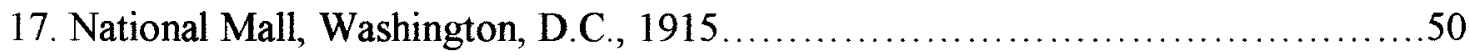

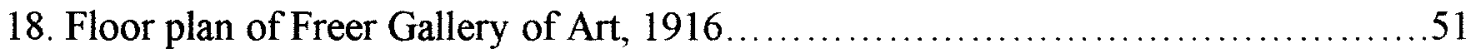

19. Photograph of gallery space, Freer Gallery of Art, $1925 \ldots \ldots \ldots \ldots \ldots \ldots \ldots \ldots \ldots \ldots$ 
20. Diagram of National Mall, 2005.

21. Elevation of renovated Freer Gallery of Art, 1990. .52 


\section{TABLE OF CONTENTS}

PAGE

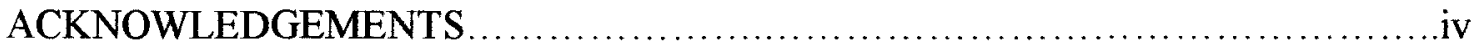

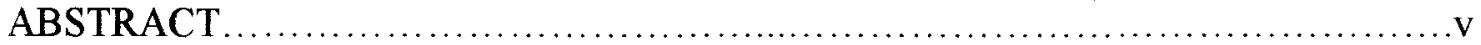

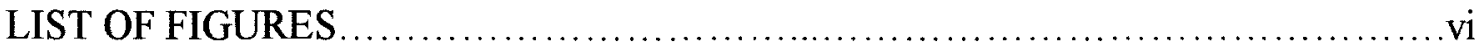

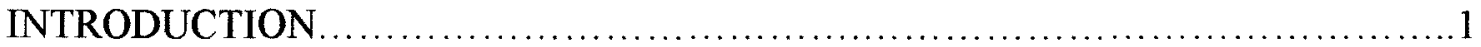

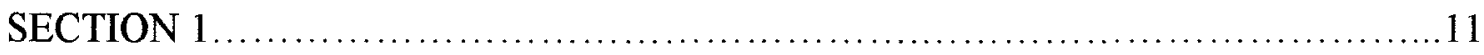

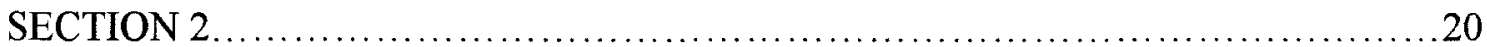

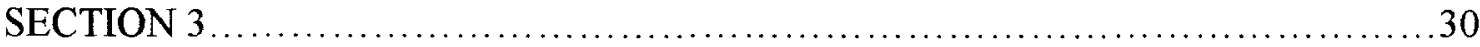

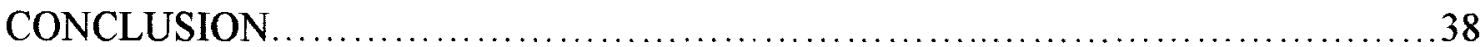

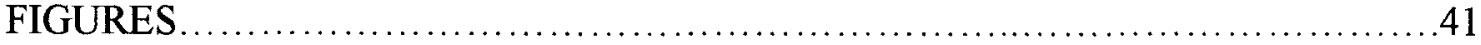

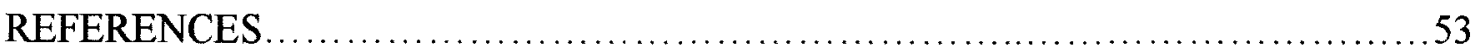

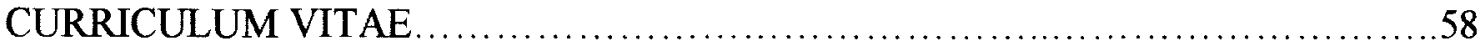




\section{INTRODUCTION}

This thesis project explores the development of the Freer Gallery of Art, regarded as the first national public art museum on the National Mall. ${ }^{1}$ The wealthy Detroit industrialist Charles Lang Freer (1854-1919) first offered his collection of American and Asian art to the Smithsonian Institution in 1903 . However, that traditionally scientific institution did not accept Freer's proposal until 1906, when President Theodore Roosevelt voiced his interest in what Freer had compiled. Under pressure from Roosevelt, the Smithsonian adopted the collection and assumed the responsibility of caring for the museum that would house it.

The Freer Gallery had on its surface the promise of education, but above all it represented private interests and conveyed political implications. For Freer it was the culmination of his life's work, and fulfilled his desire to build a permanent center for scholarship and for the protection of his collection. For Roosevelt the creation of an art museum during his presidency signified political advancement and set a precedent for continuing the development of the National Mall. By supporting the Freer collection, the

\footnotetext{
${ }^{1}$ Thomas Lawton and Thomas W. Lentz, Beyond the Legacy: Anniversary Acquisitions for the Freer Gallery of Art and the Arthur M. Sackler Gallery. Washington, D.C.: Smithsonian Institution, 1998. The museum is sometimes referred to as the first national public art museum, as Milo Beach, former director of the Freer Gallery, explains on page 7, in the foreword to the catalog Beyond the Legacy. Since the Freer was the first art museum of the Smithsonian, and the Smithsonian is now the national museum system, the Freer is considered the first national art museum. For further discussion on national museums, see Allan Wallach, Exhibiting Contradiction: Essays on the Art Museum in the United States. Amherst: University of Massachusetts Press, 1998. Chapter Two, "William Wilson Corcoran's Failed National Gallery," frames the Corcoran Gallery in Washington, D.C. as the original national museum of art, but because it was not accepted by the Smithsonian for funding until after the creation of the Freer Gallery, its title is not official.
} 
President promoted a patriotic art model that displayed American art and showed the world that the United States had an incomparable collection of Asian art. Although the Freer Gallery was patriotic in the sense that it excluded European art in order to elevate the status of American art, in many ways the museum still embraced European tradition. Its founder thought of himself as a modern-day Medici. Freer amassed work by American and Asian artists, but his collection revolved around the work of James Abbott McNeill Whistler, an American artist who was active not in America but Europe. Further, the museum was built in an Italian style, and on a National Mall that was designed by a Frenchman, Pierre Charles L'Enfant.

The resulting museum, finally opened in 1923, followed Freer's personal ideas about aesthetics so stringently that its methods of display were not conceptually accessible to the average American. What the museum represented will be detailed through an examination of Freer's biography, his collecting style, and the resulting museum structure. Reactions of critics present at the building's opening also help to explain that the museum was accessible to people already acquainted with Freer's aesthetic preferences and to scholars who studied Asian art.

There are varying points of view on the nature of Freer's collecting, as much as there are points of view on the importance of the collection that he left behind. The curators and directors of the Freer Gallery itself have published most of the available literature on the man and his collection. ${ }^{2}$ The publications from the Freer Gallery depict Freer as a generous benefactor to the nation who was interested in accumulating the best possible representations of Asian art for the education of the public. On the other hand,

\footnotetext{
${ }^{2}$ See Thomas Lawton and Linda Merrill, Freer: A Legacy of Art, Washington, D.C.: Smithsonian Institution, 1993; and David Park Curry, James McNeill Whistler at the Freer Gallery of Art, Washington, D.C.: Smithsonian Institution, 1984.
} 
scholars not affiliated with the Smithsonian museum write about Freer with an interest in casting light on the personal identity that he tried to keep very private. ${ }^{3}$ There are references to Freer as a homosexual recluse afraid of exposure to public scrutiny, an elitist aesthete who felt compelled to educate the ignorant masses, an agnostic who sought spiritual refuge in exotic material objects, and a shrewd businessman who negotiated his way into a namesake on the National Mall. ${ }^{4} \mathrm{He}$ probably embodied some aspects of all these descriptions and observations.

The definition of "aesthete" usually involved the aspect of wealth, because the aesthete would be able to afford the time to study art independently and to contemplate in the appropriate, peaceful home setting. As David Carrier explains, an aesthete "knows that those who lack the leisure to appreciate art as he does really are missing something... Being an aesthete is a way of life." Art critics such as John Ruskin and Walter Pater published essays on the aesthetic study of art in the late nineteenth century and stressed the act of contemplation and careful observation when approaching a work of art. Pyne comments that Ruskin and Pater were just a few of the authors that Freer read when forming his collecting aesthetic. ${ }^{6}$

\footnotetext{
${ }^{3}$ Henry Nichols Blake Clark, "Charles Lang Freer: Patron of American Art in the Gilded Era," M.A. thesis, University of Delaware, 1975; and Helen Nebeker Tomlinson, "Charles Lang Freer: Pioneer Collector of Oriental Art," Ph.D. diss., Case Western Reserve University, 1979, are graduate papers on Freer's biography.

${ }^{4}$ Ronald Anderson and Anne Koval, James McNeill Whistler: Beyond the Myth. New York: Carroll \& Graf, 1994, 460. "A homosexual, he was careful to hide his sexual inclinations of the age." I have not found other commentary to verify that, however. Regarding his elitist views, see Clark, 43 , where he describes Freer's "superior and exclusive attitude." Regarding his possible religious inclinations, see Kathleen Pyne, "Portrait of a Collector as an Agnostic: Charles Lang Freer and Connoisseurship" The Art Bulletin 78.1, 83. Pyne frames Freer as an agnostic who looked at art as a means of moving away from "physicality and moving toward a higher, more spiritual state of being."

${ }^{5}$ David Carrier, "Introduction: England and Its Aesthetes," in England and Its Aesthetes: Biography and Taste. Essays by John Ruskin, Walter Pater, and Adrian Stokes. Amsterdam: G + B Arts International, 1997, 5.

${ }^{6}$ Pyne, 79. She had access to inventory lists from Freer's home, created after his death. She comments that he had "at least eight volumes" of Pater's works, in addition to books by Ruskin, Wilde and Rossetti.
} 
Author Richard McLanathan comments that American industrialists who grew rich in the decades after the Civil War turned from collecting American landscapes that had once been popular to buying European art as a statement of elite tastes. Because of this preference for European artists, McLanathan continues, many American artists moved to Europe to study European techniques and to make a living. ${ }^{7}$ It was really in the latter part of the nineteenth century, then, that wealthy Americans desired to establish themselves within the Western art world, creating their own collecting identities in competition with Europeans. Americans sought balance between their monetary wealth and their cultural wealth, and so amassed collections that would establish them as aesthetically sensitive and put them in the position to influence a collecting style for the less wealthy to follow. ${ }^{8}$ Freer, an aesthete, used his industrialist railroad wealth to join Japanese-inspired works by James Abbott McNeill Whistler and actual Asian works that he thought visually complemented each another. ${ }^{9}$ The concept of what was considered to be "art" was fluctuating during this period, as industrialization, travel, and politics offered opportunities for cultural education and the importation of objects from other countries, namely Japan and China. ${ }^{10}$

\footnotetext{
${ }^{7}$ Richard McLanathan, Art in America: A Brief History. 2 d ed. San Diego: Harcourt Brace Jovanovich, 1994. 148-150. "No longer, as in the days of Cole, Kensett, Bierstadt, and Church, were American artists generally respected and collected. No longer did they seem to speak the same language and share the same ideals as their fellow citizens." He uses Whistler, Cassatt and Sargent as examples of expatriate American artists.

${ }^{8}$ Charlotte Gere and Marina Vaizey, Great Women Collectors London: Philip Wilson Publishers Limited, 1999, 123. "[Great American cities] needed a cultural framework to match their industrial might, and lacking either old royal collections or war booty to annexe, the responsibility fell on individuals to supply culture, in the form of works of art and buildings to house them." Isabella Stewart Gardner of Boston was one of these early precedent setters. She opened her museum at Fenway Court in 1902. For more about her, see Morris Carter, Isabella Stewart Gardner and Fenway Court. 2d ed. Boston: Houghton Mifflin Company, 1940.

${ }^{9}$ Richard L. Wilson, The Potter's Brush: The Kenzan Style in Japanese Ceramics. Washington, D.C.: Smithsonian Institution, 2006, 33. "Through Whistler, Freer acquired a critical paradigm: Japanese art embodied an emancipation from realism, detail, and didacticism."

${ }^{10}$ For more on the development of trade relations between East and West, see Constance Jing Shue Chen, "From Passion to Discipline: East Asian Art and the Culture of Modernity in the United States, 18761945 ," Ph.D. diss., University of California, Los Angeles, 2000 , xiii. She also addresses why objects from
} 
In 1853, Commodore of the American Navy Matthew C. Perry and his fleet opened Japanese ports to Western trade. ${ }^{\text {" }}$ Prints by Japanese artists such as Hokusai and Hiroshige depicting local landscapes and people made their way to Europe and America, and aroused Westerners' curiosity about the aesthetics of the ukiyo-e print type. The popularity of Japanese art flourished in Europe over the following decades. The American Civil War drew American collectors' attention away from developments in the art world, but their interest in Japanese culture was renewed later in the nineteenth century by the popularity of Japonisme in France and exhibits in American fairs. ${ }^{12}$

The Japanese aesthetic was most appreciated and popularized by artists in Paris, who depicted Japanese pottery and prints in their paintings and echoed in their own works the colors, line styles and compositions seen in Japanese prints. Edouard Manet, Paul Gauguin, and Edgar Degas are the more famous of French artists who during the Japonisme movement collected and emulated Japanese art in their paintings. ${ }^{13}$ London artists incorporated Japanese style more into decorative or "minor" arts, such as ceramics and furniture making, than painting. ${ }^{14}$ Whistler bridged the Japonisme gap between France and Britain; he worked in both countries during the Japonisme movement, and produced minor and fine art that reflected his interest in Japanese style.

the East became popular, "Feeling increasingly alienated by their mechanized world. various connoisseurs became interested in East Asia as a source of cultural rejuvenation."

${ }^{11}$ See Frank Whitford, Japanese Prints and Western Painters, New York: Macmillan Publishing Co., Inc., 1977 , for an account of Perry's landing and Japanese reaction.

${ }^{12}$ Gabriel P. Weisberg, Japonisme Comes to America: The Japanese Impact on the Graphic Arts, 18761925, New York: Harry N. Abrams, Inc., Publishers, 1990, 16. Ayako Ono, Japonisme in Britain: Whistler, Menpes, Henry, Hornel and nineteenth-century Japan, London: RoutledgeCurzon, 2003, 1. Ono defines Japonisme as a European phenomenon in which artists "assimilated elements of Japanese art, and from these they formed their own style. It could be generally agreed that it is an attempt to understand and adapt the essential qualities of Japanese art."

${ }^{13}$ Jay M. Kloner, "The Influence of Japanese Prints on Edouard Manet and Paul Gauguin." Ph.D. diss., Columbia University, 1968.

${ }^{14}$ Whitford. 235. 
When Asian art reached America, artists were affected less than collectors. Weisberg notes that Americans competed with Europeans for Asian imports. ${ }^{15}$ While Japonisme did not surface much in Americans' painting, American designers had a reaction much like the British, and created minor arts with Japonisme in mind. Louis Comfort Tiffany founded Tiffany Glass and Decorating Company, where he designed Japanese-inspired glass, while Frank Lloyd Wright incorporated Japanese taste into his architectural designs. ${ }^{16}$ A paradox would surface at the turn of the century, when the positive sentiments that Westerners had toward the arts of Asia would not match the negative reaction to Japanese immigrants into the United States. The 1876 Philadelphia Centennial International Exhibition and the 1893 World's Columbian Exposition in Chicago enlightened Americans on the topics of Japanese culture and architecture. However, as Conn mentions, there was a fine line between anthropological interpretations of Japan as the Other and artistic appreciation of its culture. ${ }^{17}$

Lecturers and scholars such as Ernest Fenollosa inspired collectors in the very early twentieth century to acquire Asian art, most of which can now be found in museums like the Cleveland Museum of Art, the Boston Museum of Fine Arts, the Isabella Stewart Gardner Museum in Boston and the Walters Art Gallery in Baltimore. ${ }^{18}$ Other prominent

\footnotetext{
${ }^{15}$ Weisberg. 16.

${ }^{16}$ Lionel Lambourne, Japonisme: Cultural Crossings between Japan and the West, London: Phaidon Press, $2005,172$.

${ }^{17}$ Steven Conn, "Where is the East? Asian Objects in American Museums, from Nathan Dunn to Charles Freer." Winterthur Portfolio 35.2/3 (Summer 2000), 167. Conn and David Carrier, Museum Skepticism, Durham: Duke University Press, 2006, 138, both comment that Western bias is inescapable in classifying Asian art as "art," because the art is being appropriated into a culture that did not produce it, and is shown in a museum context for which it was not intended. See also Edward Said, Orientalism, New York: Random House, Inc., 1979, and Timothy Mitchell, "Orientalism and the Exhibitionary Order," in The Art of Art History: A Critical Anthology, Oxford: Oxford University Press, 1998.

${ }^{18}$ Constance Jing Shue Chen, "Transnational Orientals: Scholars of Art, Nationalist Discourses, and the Question of Intellectual Authority," Journal of Asian American Studies 9.3 (Oct 2006). She presents the influence of advisors besides Fenollosa, by discussing the influence that Okakura Kakuzo and Kojiro Tomita had on Gardner and the officials of the Boston Museum of Fine Arts.
} 
collectors were located in Philadelphia and Chicago. ${ }^{19}$ The idea of an art museum on a national level was merely surfacing, however, in Washington, D.C., where powerful officials like Roosevelt were thinking of how to create a national center that would solidify American identity to compete with the cultural identities of other world powers. ${ }^{20}$

Stephen Levine describes Roosevelt as an aesthete who wished to create a unified artistic type, or "nationalist aesthetic," for American art that did not rely on European precedents. Levine writes, "Americans were exceptional; they began the nation, according to Roosevelt, without divisions of class, inheritance, or other vices that permeated European societies. ${ }^{21}$ Levine discusses Roosevelt's agenda to beautify Washington, D.C. On that agenda, among other things, was acquiring the Freer collection. Levine does not elucidate, however, items on that agenda, including the fight to accept Freer's art collection or Roosevelt's interest in beautifying the National Mall. So here I wish to establish the significance of the Freer collection, through an examination of the circumstances under which it became the first national public art museum on the National Mall.

Authors have addressed the birth of the Freer Gallery as a case study of the intersection between art and politics. Richard Collin treats Roosevelt's interference as a

\footnotetext{
${ }^{19}$ Collecting in the Gilded Age: Art Patronage in Pittsburgh, 1890-1910, Pittsburgh: Frick Art \& Historical Center, 1997. The essays describe the types of collections amassed by such Pittsburgh industrialists as the Frick family. See Ruth Krueger Meyer and Madeleine Fidell Beaufort, "The Rage for Collecting: Beyond Pittsburgh in the Gilded Age," which looks at collecting outside of Pittsburgh.

${ }^{20}$ Books that chronicle the development of the National Mall include Frederick Gutheim and Antoinette J. Lee, Worthy of the Nation: Washington, D.C., from L'Enfant to the National Capital Planning Commission. 2d ed. Baltimore: Johns Hopkins University Press, 2006; Richard Longstreth, ed. The Mall in Washington, 1791-1991. Washington, D.C.: National Gallery of Art, 1991; John Reps, Monumental Washington: The Planning and Development of the Capital Center. Princeton: Princeton University Press. 1967.

${ }^{21}$ Stephen L. Levine, "Race, Culture, and Art: Theodore Roosevelt and the Nationalist Aesthetic." Ph.D. diss., Kent State University, 2001, 4. Levine comments in Chapter Two that cultural pride stemmed from victory in the Spanish-American War, from which the United States "had emerged as a major imperial power" (38-39). Levine also discusses that Roosevelt's desire to retain a pure American culture was simply cultural pride, and not racism, as many scholars suggest.
} 
stroke of luck for Freer, the rags-to-riches philanthropist. ${ }^{22}$ Levine uses Freer's case as an example of Roosevelt's methods of gaining publicity. ${ }^{23}$ What has not been sufficiently addressed is the symbolism of the museum and its place as a private building in a public space. Initially, the gallery could not be considered representative of a national culture or a democratically accessible art type because it was based on one man's ideas. Those ideas were available to a limited number of people who intimately understood Freer's aims. On a level removed from the elitist aesthetes in Freer's circle, journalists and those who had access to newspapers could follow the museum's development over the course of the seventeen years it took to build, so they would know how to react to the museum based on what they read about Freer. The study that follows will trace the development of the collection and the museum within the context of America's political status at the turn of the century.

The first section of this study addresses how Freer advanced his preferences for Asian and American art. Correspondence between Freer and his friends illustrates his philosophy of collecting and his theories of seeing art from the East and West together. He did not develop those theories on his own, but was greatly influenced by scholarly friends such as Fenollosa, and artist friends such as Abbott Handerson Thayer, Thomas Wilmer Dewing, Dwight William Tryon, and of course Whistler. This section explains how he applied those theories to the construction and decoration of his own home in order to present his collection in what he thought was the best environment for contemplation. He extended those theories of private space into the public realm when he

\footnotetext{
${ }^{22}$ Richard Collin, Theodore Roosevelt, Culture, Diplomacy, and Expansion, Baton Rouge: Louisiana State University Press, 1985. Collin's chapter "Cultural Expansionism: Theodore Roosevelt and Charles Freer s New National Art Museum" follows Freer's determined effort to leave his collection to the Smithsonian. However, he neither analyzes the political significance of the museum, nor what the museum eventually looked like once it opened.

${ }^{23}$ See Lawton and Merrill, Lentz and Lawton.
} 
considered the construction of his namesake museum. ${ }^{24}$ Explaining Freer's background and his establishment as a collector lays the foundation for the second section, which details how the public museum reflected private aesthetic views.

Freer retired in his forties from the railroad business to collect art full time. His appreciation of art, his aesthetic philosophy, and the establishment of his identity as an art connoisseur will all be explored here. For many years Freer refined his notion that object and observer interact so that the observer looks beyond the formal qualities and feels the object's underlying sense of beauty. He reinforced his philosophy by collecting objects that also related to one another. Ultimately, Freer created a collection with a communicable notion of beauty so strong that he felt the collection was worthy of being housed on the National Mall.

The second section follows Freer's collection from its storage in Detroit to its permanent destination in Washington, D.C. In this section I deal particularly with the designs for the museum and the ways in which the museum is an obvious representation of Freer's views. By placing that private collection on the National Mall, Roosevelt intended to present a collection that illustrated America's progress. However, the end result was not one that immediately made sense to the viewer unless he or she knew Freer's biography beforehand and had followed the press reports on the advancement of the museum building. Therefore, the museum was an embodiment of the personal in the public realm. In this case, it was Freer's aesthetic view presented to the public in such a private way that it did not convey the national message of an art form for all Americans.

\footnotetext{
${ }^{24}$ For a European parallel to this American aesthete, see Valerie Mendelson, "A Citadel Behind Walls? The House of the Amateur in Late Nineteenth-Century France." $\mathrm{PhD}$ diss, The City University of New York, 2004,3 . She discusses the amateurs, who "adopted an identity heavily inflected with aristocratic ideals, and they installed their collections according to the centuries-old traditions of harmony and balance... The positivist idea of art reflecting a period or a country's culture that was enacted in the museum. was countered in the home of the amateur by a notion of the artwork as changeable and interactive."
} 
To conclude, I explain the extent to which Freer's vision has stood the test of time. The Smithsonian has renovated the museum in attempts to attract a varied public, beyond scholars doing research. Wall texts now explain the seemingly out-of-place presence of turn-of-the-century American works in a space that is largely dedicated to the study of Asian art. In addition, the attachment in the 1980s of the underground Arthur M. Sackler Gallery has increased the focus on Asian art by providing spaces for the exhibition of contemporary shows.

This project grew out of observations I made on several visits to the Freer Gallery and a subsequent end-of-semester paper I wrote for a graduate seminar on Whistler's place in nineteenth-century American art. As a student interested in the role that museum curators and educators play in the development of public knowledge, my goal for this project is to focus on the individuals behind public collections and the importance of public museum development in the beginning of the twentieth century, when public officials finally implemented designs for the National Mall over one hundred years after L'Enfant's original design in 1791. 


\section{SECTION 1: \\ ONE COLLECTOR'S VISION}

Charles Lang Freer's quest to develop himself as an art appreciator, aesthete, and connoisseur came after earlier life events of a radically different kind: traumatic events that prematurely ended his childhood and intense days in the quickly developing railroad industry. 'Freer's mother died when he was a teenager, and his father eventually became ill. Several of his siblings also developed serious, sometimes fatal, illnesses. ${ }^{2}$ He quit school to support his family, first with a job at a cement factory, and then at a grocery. When Frank Hecker hired him for a local railroad company, he stayed in the railroad business until retirement. Freer moved to Detroit, Michigan, in 1880 to help set up a freight car construction business and eventually organized several sizable mergers, proving himself to be a successful businessman with the means to retire early. ${ }^{3}$

\footnotetext{
${ }^{1}$ See Mieke Bal, "Telling Objects: A Narrative Perspective on Collecting," in Grasping the World: The Idea of the Museum. Aldershot: Ashgate Publishing Limited, 2004; Werner Muensterberger, Collecting: An Unruly Passion. San Diego: Harcourt Brace \& Company, 1995; and Susan M. Pearce, Museums, Objects, and Collections, Washington, D.C.: Smithsonian Institution, 1992, for discussions on psychoanalyzing collectors in general. From Muensterberger's point of view, it could be to compensate for childhood loss and poverty: a way to find serenity amongst a houseful of pretty, costly, comforting objects. A collector traumatized in childhood "requires symbolic substitutes to cope with a world he or she regards as basically unfriendly, even hazardous. So long as he or she can touch and hold and possess and, most importantly, replenish, these surrogates constitute a guarantee of emotional support," (21). Pyne psychoanalyzes Freer specifically, attributing his collecting lifestyle to a desire to compensate for early loss.

${ }^{2}$ Agnes Meyer, Charles Lang Freer and His Gallery. Washington, D.C.: Freer Gallery of Art, 1970, 18. "He intimated that there was in his family a history of what could only have been congenital syphilis which had at times incapacitated some of his forebears," and was the reason he never married. Tomlinson refers to Freer's collection as his child: the museum was "in embryo" upon its acceptance, an infant in the galleries of Freer's home, and a child once museum construction began. "His collection was an extension of himself, the single legacy of his life. It bore his personal imprint, it represented his mark on the world. He nurtured it like a child, conscious of its needs for balance, authenticity, safety, and growth." (692).

${ }^{3}$ Lawton and Merrill, 14.
} 
In the 1880 s, Freer met Howard Mansfield, an attorney who owned about 300 Whistler etchings. Freer was impressed with the artist's work. ${ }^{4}$ His appreciation for Whistler's art would only increase over time, beginning with the purchase of the artist's etchings in 1887 . In 1890 Freer went to London to meet Whistler, which demonstrated the budding collector's desire to collaborate directly with the artist. Their relationship grew strong over the following years, evidenced in the flattering words they wrote of one another, as well as in the sheer number of Whistler's work accrued by Freer - now considered to be the largest collection of Whistler's art. ${ }^{5}$

Whistler spent little time in America. He was born in 1834 in Massachusetts, but as a child lived in Russia, where his father worked on railroad construction. He later returned to America to attend West Point. At the age of twenty, Whistler moved to Europe to be an artist, living first in Paris and then in London. His works painted in the 1860 s and 1870 s reflect his participation in the vogue of collecting Japanese prints. However, prints were not Whistler's only Asian inspiration. He was “avidly interested in a wide variety of Oriental production," such as Japanese and Chinese porcelain, screens, carpets and kimonos. ${ }^{6}$ For instance, Whistler's Caprice in Purple and Gold, No. 2: The Golden Screen, painted in 1864 and now in the Freer collection, features a kimonodraped model examining a print (Figure 1). A large golden screen fills the background, and a porcelain vase holding cherry blossoms sits in the lower left corner. Whistler

\footnotetext{
${ }^{4}$ Lawton and Merrill, 18. At the sight of Whistler's work, Freer supposedly paced the floor. called Whistler a genius, and began "uttering large adjectives."

${ }^{5}$ With Kindest Regards, edited by Linda Merrill, Washington, D.C.: Smithsonian Institution, 1995, is the published collection of correspondence between Whistler and Freer. Concerning his portrait, "[Whistler] is making me look like a pope, but then that is all right for there will of course, be little of Freer in it. It will surely be all Whistler!!" Freer to Hecker 13 June 1902, Freer Gallery Archives.

${ }^{6}$ Kloner, 64.
} 
emulated the flat, shadow-less quality of his beloved Japanese prints, so the viewer must assume the existence of foreground and background

The artist's nocturnes of the following decade were much looser, softer, and less dependent on the print style of his earlier paintings. Nocturne in Blue and Silver: Cremorne Lights (Figure 2), painted in 1872, is more reminiscent of "Japanese painting on silk with water-based pigments and soft brushes." ${ }^{77}$ Whistler took his interest in depicting waterside scenery to Venice, where he spent a year producing watercolors, pastels and etchings of the city. Freer's first purchase of Whistler's work was a set of Venice etchings, in 1887 (Figure 3). Three years later, upon his first meeting with Whistler, Freer bought the artist's 1889 etchings of Amsterdam. It became Freer's goal to collect as many of Whistler's prints as possible. ${ }^{8}$ As the years passed and the men's friendship deepened, Freer expanded his goal to include Whistler's pastels and paintings. Whistler trusted Freer because Freer was like no other collector at the time - he modeled himself after Renaissance era patrons like the Medici, getting to know his artist friend personally instead of using intermediary art buyers, and referring to his purchased works as jointly owned by artist and patron. Whistler was a well-known and sensationalized figure in his time, written about in newspapers and books not only for his revolutionary artistic style, but also for his involvement in public disputes and lawsuits. ${ }^{9}$

While Whistler was the first artist to affect Freer personally, he was not the only American artist in Freer's collection. He was also close to Americans Thomas Wilmer Dewing, Abbott Handerson Thayer, and Dwight William Tryon. Those artists seemed to

\footnotetext{
Whitford, 139.

${ }^{8}$ Lawton and Merrill, 42. "Freer's remains the most comprehensive group of Whistler prints ever assembled."

${ }^{9}$ Whistler sued the writer John Ruskin for libel when Ruskin criticized Whistler's work. Whistler also argued with Frederick Leyland over how to decorate Leyland's dining room, now known as the Peacock Room.
} 
follow Whistler's style with their hazy, muted colors that emphasized the surface quality of their painted works (Figures 4-6). ${ }^{10}$ It also helped that the men kept to the same social circles and shared elitist beliefs about the superiority of their aesthetic styles.

Inspired by the artistic stimulation that Whistler and Fenollosa received from their own collections of Asian art, Freer became curious about extending his art collection into the realm of the East. Freer's trips to Asia began in the 1890s; he returned to Japan, China, India and Egypt several times over the following decades. ${ }^{11}$ Fenollosa, who had developed the Asian department at the Boston Museum of Fine Arts, and who taught art and philosophy at Tokyo University, acted as Freer's consultant and introduced Freer to collectors and vendors abroad. ${ }^{12}$ Fenollosa thought that Americans could learn from the use of harmony and space in Japanese art. He was convinced that there would be an artistic revolution that would meld Eastern and Western artistic traditions into "a common, but as yet unknown type, the type of the world's future." Like Freer, Fenollosa valued Whistler's artwork, because he believed that it represented his aesthetic theory: Whistler "is the first great master who comes after the union of the East and the West, the first who creates naturally and without affectation in their mingled terms. ${ }^{\prime 13}$ This idea

\footnotetext{
${ }^{10}$ Clark explains that "the artists showed Freer the quality of American 'tonalist' art and warned him that only a very small circle would appreciate it," 41 . For more on Tryon and Freer's relationship, see Linda Merrill, An Ideal Country: Paintings by Dwight William Tryon in the Freer Gallery of Art, Washington. D.C.: Smithsonian Institution, 1990. For more on Dewing and Freer's relationship, see Lee Glazer. "A Modern Instance: Thomas Dewing and Aesthetic Vision at the Turn of the Century," Ph.D. diss., University of Pennsylvania, 1996.

"See Ann C. Gunter, A Collector's Journey: Charles Lang Freer and Egypt. Washington. D.C.: Smithsonian Institution, 2002. Freer bought from private collectors and dealers while on his trips, relying on the dealers' knowledge of the objects as assurances of their authenticities. Once the museum opened, director John Ellerton Lodge reclassified some of the items in Freer's collection. For details of Freer's Asian collection, see the chapter "The Asian Tours" in Lawton and Merrill, 59-97, and "Between Kenzan and Freer" in Wilson, 22-40. The most abundant items in Freer's Asian collection were Rakka ware from Syria, scrolls and Kenzan-style ceramics from the Japanese Edo period, and scrolls and ceramics from the Song and Ming dynasties of China.

${ }^{12}$ For Fenollosa's biography, see Lawrence W. Chisolm, Fenollosa: The Far East and American Culture. New Haven: Yale University Press. 1963.

${ }^{13}$ Fenollosa quoted in Pyne. 93.
} 
formed the basis for Freer's collecting habits, in gathering ancient pieces that would reflect and complement Whistler's techniques, and ultimately support the idea that there existed a universal harmony in art that bridged countries and cultures.

Freer explained how his collection encapsulated this concept of universal harmony: "My great desire has been to unite modern work with masterpieces of certain periods of high civilization harmonious in spiritual suggestion, having the power to broaden esthetic culture and the grace to elevate the human mind.." ${ }^{14}$ For him, nothing needed verbal explanation - the viewer should be able to feel the connections between the objects he chose to assemble, even if one was an ancient artifact from Egypt and another a sketch by Whistler.

Freer's goal was not to reflect an anthropological chronology of artifacts, but to show, for instance, that the glaze on a pot can be complemented by and compared to the diffuse application of oil on canvas. (Figure 7) He preferred the runny, opaque drops of glaze that drifted down the sides of some Japanese and Korean pottery over the traditional and precise patterns on blue and white china, which artists such as Whistler collected and even incorporated into paintings. As Freer commented, "The underclays gray, yellow, olive, brick-red, or stone-brown - which I have already compared to old papers, are full of the dissolved light of opaque surfaces, a diffused luminosity almost peachy and down-like. And it is this sort of cool depth which Whistler, even in his oil work, loved to prepare upon the tea-jar grounds of his canvases." ${ }^{15}$ The cloudy, earthy quality of glazed ware complemented the broad strokes on a Thayer seascape, the grassy hills in Tryon's work, or the loose, dark, dreamlike locations in Whistler's nocturnes.

\footnotetext{
${ }^{14}$ This is Freer's most oft-quoted statement, found, for example, in Lawton and Lentz.

${ }^{15}$ Curry, 22.
} 
Such a pairing represented the aesthetic theme that Freer was convinced united all "beautiful" pieces. His appreciation for glazes was so deep that he commissioned glazed ware that resembled pottery from other cultures from a Detroit potter, Mary Chase Perry Stratton of Pewabic Pottery (Figures 8, 9). Curry remarks that Freer's patronage of American pottery that resembled old Japanese pottery supported his goal of uniting similar-looking pieces. ${ }^{16}$

His preferences showed through on many occasions in his letters to friends. From Munich, he wrote to his friend and next-door neighbor Frank Hecker, "to my surprise I find the present exhibition of modern international art very instructive; beautiful in no sense, and saved by complete rottenness by Whistler, Sargent, Melchers and few others, but valuable in showing to what depths of imbecility the great horde of modern painters have fallen." ${ }^{17}$ His faith in his American artist friends was strong, and obviously he considered their softer works superior to the more visually jarring colors of the developing modern European style.

After Whistler died in 1903, Freer would have been sensitive to the display of his friend's works. "I cling to [artworks] most tightly and jealously hide them from the sight of the curious, letting only people of the really right sort see them at all. It is about as fine an accomplishment to keep beauty away from the followers of the ugly as it is to spread it before those who truly love it," said Freer. ${ }^{18}$ Such commentary demonstrates how Freer was selective about who could have access to viewing the collection. He wrote to Whistler's executrix, Rosalind Birnie-Philip, “Mr. Whistler's art needs no explanation. The worthy ones will by degrees, in their own appreciation, see and understand." Those

\footnotetext{
${ }^{16}$ Curry, 19.

${ }^{17}$ Freer to Hecker, 15 July 1901. Freer Gallery Archives. This comment he made after seeing art in Paris.

${ }^{18}$ Freer to Birnie-Philip, 16 September 1903.
} 
who did not understand "will pass into nothingness," said Freer. ${ }^{19}$ His commentary brings to light his desire to protect his collection, and to present it in such a context as would educate the public properly, in his mind. In 1904, Freer collaborated with the Copley Society of Boston on the Whistler Memorial Exhibition. The positive reaction of the American public was in contrast to the customarily critical reviews Whistler had received during his life in Europe. Freer considered the American enthusiasm for Whistler works promising, which supposedly contributed to his decision to leave his collection to America. $^{20}$

Freer surrounded himself with the aesthetic ideals he appreciated in his home in Detroit (Figure 10). Located on Ferry Avenue, his house was designed by Wilson Eyre, Jr., and built in the Shingle Style, which scholars comment was an unusual contrast to its neighbors, particularly Hecker's palatial mansion next door. The earthy quality of the shingles and the enveloping landscaping effectively camouflaged the house and insulated Freer from the outside world. The wall treatments he enlisted his artist friends to complete further separated Freer's house from its city environment and created an inward-looking atmosphere wherein Freer had the privacy to contemplate his art holdings.

Historian Thomas Brunk has described Freer's house in Detroit as a trial run for the museum he eventually founded on the National Mall. ${ }^{21}$ At the heart of Brunk's argument is the construction of gallery space in Freer's home, suggesting that Freer could surround himself in an aesthetic environment whenever he wanted, and he could

\footnotetext{
${ }^{19}$ Freer to Birnie-Philip 30 September 1903. Freer Gallery Archives.

${ }^{20}$ Merrill, Regards, 39.

${ }^{21}$ See Thomas W. Brunk, "The House That Freer Built," Dichotomy 3 (Spring 1981): 5-53; and Thomas W. Brunk. "The Charles L. Freer Residence: The Original Freer Gallery of Art." Dichotomy 12 (Fall 1999): 6147. The architecture of Freer's house is also discussed in depth in Betsy Fahlman. "Wilson Eyre in Detroit: The Charles Lang Freer House." Winterthur Portfolio 15.4 (Fall 1980): 257-269.
} 
contemplate his collection in the privacy of his own home. Linda Merrill, however, disagrees with Brunk, saying that Freer "never wanted his house to become a private museum." She explains that he kept most of the collection in a vault in the house, until he could transfer it to a museum space. ${ }^{22}$ It seems more logical, though, that he would resist building a gallery not because he disliked having a museum in the house, but because making additions might endanger the harmony and balance of rooms he had created in the original design of the house. If he did not want to create a museum, he certainly wanted to create an artistic environment, because he had his artist friends paint the walls to coordinate or "harmonize" with their own paintings that would be hung in the house.

Freer commissioned works from Tryon, Dewing, and Thayer specifically to fit in certain parts of the house, always citing his desire to achieve harmony and balance through the right color values or line qualities. One of his rooms featured paintings of the seasons, hung in cycle around the perimeter of the room (Figure 11). Tryon and Dewing, who had backgrounds in interior decorating, spent months communicating with Freer about the right fabrics and paints for the walls, and which walls would be best to hang with paintings. Tryon stippled his area of the house with Dutch metal and deep tones of brown and blue. Dewing, on the advice of his wife Maria, a writer on interior decorating, created iridescent wall treatments with lighter tones.

In 1904, Freer went back to Eyre to create an addition to the house. Freer had just purchased the Peacock Room and was having it shipped from London to be re-erected in his home ${ }^{23}$ Once it was set up in Detroit, Freer used the shelving of the room not to

\footnotetext{
${ }^{22}$ Lawton and Merrill. 29

${ }^{23}$ See Linda Merrill, The Peacock Room: A Cultural Biography. Washington, D.C.: Smithsonian Institution, 1998. Whistler finished the room, originally the dining room in Frederick Leyland's house in London, in 1877. The room caused controversy and was well known because it was not what Leyland wanted, but it certainly reflected what Whistler wanted. It is the only surviving interior by Whistler.
} 
display the blue and white china for which the room was intended, but to store his collection of glazed ware (Figure 12). Freer and Eyre worked together again in 1910, when Freer needed more room to put together the collection he would leave to the Smithsonian upon his death (Figure 13) ${ }^{24}$ He spent his last years in his new gallery spaces, inspecting the quality of his collection and preparing it for cataloguing.

\footnotetext{
${ }^{24}$ Brunk 1999, 112-119. In 1921, two years after Freer's death, the Merrill-Palmer School of Homemaking of Detroit bought his house. It was not until 1952 that the school made major renovations to the house, such as removing walls, altering the gallery, and painting the walls and woodwork. In 1970 the house was added to the National Register of Historic Places, and in 1981 it became part of Wayne State University's campus. According to Michigan's news web page, Dennis Tanner, "Efforts under way to save historic home that housed original Freer gallery," 13 Mar 2007, Mlive.com. Everything Michigan, the new director of the school, now the Merrill-Palmer Skillman Institute for child development studies, wants to restore the house to its original condition.
} 


\section{SECTION 2: \\ HARMONY FOR THE NATION}

In 1903 Freer pledged his art collection to the American nation, to form an art museum on the National Mall. There were conditions, however. The Smithsonian could not claim the items until after Freer's death, and the collection could never be divided, changed or loaned out. Further, only the pieces in the collection could be shown in Freer's gallery, so no visiting exhibits could be presented there. Freer's policy likely came after years of loaning his objects to outside exhibitors and museums, which often caused irreparable wear and damage. ${ }^{3}$ That he would neither allow additions after his death nor allow visiting exhibits further underscored Freer's belief in the completeness of his work. He wrote to the Smithsonian authorities who did not agree with his restrictions:

I regard my collections as constituting a harmonious whole. They are not made up of isolated objects, each object having an individual merit only, but they constitute in a sense a connected series, each having a bearing upon the others that precede or that follow it in point of time. ${ }^{2}$

According to Freer, demonstrated in the above statement, an underlying harmony pervaded his collection, uniting all the objects in it. The mainstay of that collection was Whistler, represented by more than 800 paintings, drawings, and etchings. In addition there were the dozens of works by Tryon, Thayer and Dewing. These American artists

\footnotetext{
'Merrill. 1995. Whistler was usually upset at the possibility of damage to his works, and Freer paid attention to his requests for periodic conservation.

${ }^{2}$ Lawton and Merrill. 186.
} 
were brought together with complementary qualities their works shared with the hundreds of Japanese screens and panels, and 950 pieces of Asian pottery. ${ }^{3}$

With its promises of cultural development, Washington, D.C. would have been an enticing destination for Freer's collection. He remarked on the difficulty of accomplishing "things of higher interest for Detroit," adding, "I fear that the majority of our citizens have very little real interest in culture." ${ }^{\prime 4}$ The Detroit Institute of Art was not financially stable enough for Freer to entrust his collection to it. Also, Detroit's notoriety for being a smoggy industrial city would have made for an unappealing location for Freer's namesake. He disliked the direction of Detroit's development and would have preferred Washington, D.C. for the beautification efforts under way there.

At the beginning of the twentieth century, the National Mall bore little resemblance to its iconic appearance today. Aerial photographs show a park-like stretch of land, covered with a largely uninterrupted mass of trees, save the Capitol Building, the Smithsonian Castle, and Arts and Industries Building (Figure 14). The undeveloped National Mall space had been reinvented in plans since L'Enfant's first suggestions in 1791. It was not until the Senate Park Commission approved the McMillan Plan in 1901 that the national center began to develop. The McMillan Plan for Washington, D.C. sparked public interest in the development of the capital city, which encouraged officials to build a city that represented the modern American architectural goal. ${ }^{5}$ Because many newspaper correspondents were based in Washington, they provided timely reports to the

\footnotetext{
${ }^{3}$ Collin, 75 .

${ }^{4}$ Freer to Moore, 26 July 1915 . Freer Gallery Archives.

${ }^{5}$ The 1893 Exposition in Chicago has been singled out as a catalyst for American urban development. referred to as the City Beautiful Movement Gutheim and Lee, 141. "The City Beautiful became a visible expression of the urban reform movement that flowered in the early years of the twentieth century, a movement and a cause. It was voiced most significantly by the planner-publicist Charles Mulford Robinson, who popularized the new unity of parks, plazas and boulevards and related it to the business progressivism of the age."
} 
public, which was funding the development through tax dollars. ${ }^{\circ}$ Prior to the Civil War, academies and small galleries like the National Academy of Design in New York and the Pennsylvania Academy of Fine Arts were privately run and were modeled on the European system of the art academy and did not include art museums. ${ }^{7}$ In the years after the Civil War, unified elite classes promoted and supported the growth of art museums, an example of which was the Boston Museum of Fine Arts (MFA), founded in 1876.

Museums like the MFA were large, but they were founded with civic groups' effort and some public money. ${ }^{8}$ As such, they were not government supported and so were not considered national public art museums. The early twentieth century was the ideal time to discuss a national museum, since Roosevelt could set a precedent for art in a country that was developing as a world power with its own cultural center.

In the matter of Freer and the Smithsonian, there was still the struggle to define the extent to which a private citizen could mold an organization meant for the public. No matter how insistent the Smithsonian representatives were in voicing their rejection, Freer was not willing to change his requirements. He claimed that his "intention in erecting the building was to house my collections and to keep them for all time separate from all others." Further, he did not trust the officials, and wanted to protect his collection: "to add to or detract from my own collections or to exhibit in my building things which might please their fancy I am sure would eventually destroy the underlying purposes of

\footnotetext{
"Reps, 139. In Chapter Six, "The Plan, the Press, and the Politicians," Reps writes about the press' role in popularizing the development of the National Mall

Alan Wallach. "Long-term visions, short-term failures: art institutions in the United States, 1800-1860," 298. in Andrew Hemingway and William Vaughan, eds, Art in Bourgeois Society, 1790-1850, Cambridge: Cambridge University Press, 1998. See also Edith A. Tonelli, "The Art Museum." in Michael Steven Shapiro, ed. The Museum: A Reference Guide, New York: Greenwood Press, 1990, 33. Tonelli notes that the instructional tools of those schools were primarily plaster casts and copies of paintings from the Louvre. She also notes that in the 1870 s wealthy Americans wanted to adapt on their own soil "the European concept of the art museum as temple and treasure house."

${ }^{8}$ Tonelli in Shapiro. 34.

${ }^{9}$ Freer to Birnie-Philip, 24 January 1905. Freer Gallery Archives.
} 
my own work." His emphasis on "my" collections and "my" building underscore the deep, private feelings for the art he had organized.

Indeed, the officials at the Smithsonian in 1905 were hesitant to accept an offer that would leave them with a large collection and such demanding restrictions. They were even surer that they did not want to accept it when their committee went to Detroit, and Freer kept them there for the four days it took to properly show them the two thousand pieces in the collection. ${ }^{11}$ The committee's subsequent refusal to accept Freer's collection did not stop Freer from proposing the offer again.

The committee was reasonably concerned with the how one man's collection would relate to the American public, especially if the public would eventually be in charge of paying for its upkeep. Charles Moore, on the McMillan Planning Commission, warned Roosevelt that Freer's collection "is a special one. It can have no possible relation to such a general and indeterminate thing as a National Art Gallery," thereby removing it as a qualified example of the national art type. ${ }^{12}$ However, Roosevelt believed that the cost of upkeep would not be much, and that accepting this collection would force the Smithsonian to expand its holdings to include art. The tension over the collection suggests that there were power struggles between the Smithsonian and Roosevelt that extended beyond Freer's collection.

At the end of 1905 Freer wrote to President Roosevelt, repeating his desire to leave his collection to the Smithsonian. Freer also proposed $\$ 500,000$ for the construction of the museum building, which Freer referred to as part of the National Museum.

\footnotetext{
${ }^{10}$ Freer to Hecker, 7 February 1905. Freer Gallery Archives.

${ }^{11}$ Levine, 158. Levine includes Freer's reaction to the Smithsonian committee, which included Alexander Graham Bell, Senator John B. Henderson and Samuel P. Langley, the director of the Smithsonian. Freer said, "What they don't know about art would fill many volumes."

${ }^{12}$ Conn 2000, 168.
} 
Roosevelt went so far as to invite Freer to the White House, an act which captured the press' attention. If the Smithsonian did not accept Freer's offer, the President promised, "I shall then be obliged to take some other method by endeavoring to prevent the loss to the United States government[.]" Further, the paintings "by Whistler alone being such as would make the whole collection of unique value - although the pictures by the Chinese and Japanese artists are of even greater worth and consequence," he wrote to the Smithsonian board, curiously emphasizing the Asian art. ${ }^{13}$

Roosevelt's emphasis on the Asian component of Freer's collection can be read as alternately progressive and odd. His commentary that the Asian art is of great worth reflects his own interests in learning about the philosophy and art of other countries. At the same time, Roosevelt's statement suggests that he is validating Freer as a symbol of White America's potential to master an understanding of world cultures. As Conn remarks, "At the turn of the century Westerners continued to view the East with an admixture of awe, condescension, curiosity, and contempt." ${ }^{14}$ Roosevelt seemed peculiarly suspicious of Asian immigrants, and commented that Asians could not be integrated into the American mainstream. ${ }^{15}$ To have a center for Asian art in the United States, then, suggests that he did not want to demonstrate that Asian culture should be accepted in America; instead, he wanted proof that America as an empire had expanded

\footnotetext{
${ }^{13}$ Freer's letter to Roosevelt and Roosevelt's resulting letter to the Smithsonian were published in The Washington Post on December 26, 1905. Levine quotes part of Roosevelt's letter in his dissertation, 160. Levine also comments that this was a popular story in the newspapers, and that "public sentiment favored Freer" (159), although he does not expand this statement.

${ }^{14}$ Conn, 167.

${ }^{15}$ Thomas G. Dyer, Theodore Roosevelt and the Idea of Race, Baton Rouge: Louisiana State University Press, 1980, 135. "Roosevelt's objection to Japanese immigration stemmed from the belief...that racial differences between Orientals and whites loomed so high as to preclude even basic understanding between the two groups."
} 
into Asia. Roosevelt appealed to American elite to lead the way in creating a model unified American culture. ${ }^{16}$

Roosevelt fostered imperialistic interests, first with conquering the American frontier, then moving beyond the boundaries of the United States. He "found his moral equivalent of the frontier in the quest for an overseas empire in Asia and Latin America." ${ }^{17}$ His participation in the Spanish-American War of 1898 was only the beginning of his involvement in foreign affairs. When he assumed the presidency in 1901 upon President William McKinley's assassination, Roosevelt determined to make the United States a world power: in the West he exerted his influence in Cuba, Venezuela, and the Panama Canal Zone; in the East he kept watch over the Philippines and mediated disputes between Russia, China, and Japan. ${ }^{18}$

The subheading of a December 26, 1905 Washington Post article announced, "[I]f Regents of Smithsonian Decline the Pictures He Will Find a Way to Keep Them for the People of the United States Forever."19 The protagonist of that excited headline was President Theodore Roosevelt, as he put pressure on the Smithsonian board members to accept Charles Lang Freer's donation of Asian and American art. The Smithsonian accepted the offer, and Freer's terms, in January of 1906.

Charles Freer once said that his collection should have "the grace to elevate the human mind." At a time when the United States was industrializing and working toward

\footnotetext{
${ }^{16}$ Slotkin, 20. "They must recover the virility and warrior spirit that had belonged to their 'fathers.' who had conquered the wilderness and built the great corporations." Slotkin's chapter "'The Great Composite American': Theodore Roosevelt and American Nationalism, 1880-1917," addresses Roosevelt's partiality for "native" white populations, which excluded immigrant groups from ever becoming completely American. In other words, immigrants could assimilate to "American standards," but would never completely be American.

${ }^{17}$ Richard Slotkin, Lost Battalions, New York: Henry Holt, 2005, 20.

${ }^{18}$ Lewis L. Gould, The Presidency of Theodore Roosevelt, Lawrence: The University Press of Kansas, 1991.

19 "Likes Freer's Gift," The Washington Post 26 Dec 1905, 1.
} 
establishing itself as a power apart from Europe, it is easy to see why Theodore Roosevelt would support a connoisseur who wanted to educate the public not only in visual art and aesthetic refinement, but also in cultures of parts of the world that for many Americans were unknown. What is so important about Freer's collection is that it does not consist of a collection of European art at its core, as so many of his contemporaries' collections did. Instead, it contained at its center juxtaposition between art by American artists, the most famous of whom was Whistler, and art by Asian artists. At a time when it was popular to collect European works, he rejected this bias in favor of promoting American artists as a statement of support for his friends.

Tomlinson remarks that Americans had little information about what Freer was offering, mostly because he was so secretive about his life ${ }^{20}$ Freer's penchant for secrecy meant that he excluded himself from many publicity opportunities. He told a Detroit author, E. Cora DePuy, that he always declined to tell stories about himself. "I fancied that you wished to refer to the collection in my care, and to this I gave consent," Freer wrote. "You will, I trust, omit from your book personal references of every kind concerning myself... and I sincerely trust that you will refrain from publishing my portrait." ${ }^{21}$ Indeed, his photo was never published, and the public was left to form its ideas about the collection based on press information and his friends' descriptions. Since Freer maintained as low a profile as possible during his lifetime, he created the collection as a reflection of himself. The collection spoke on Freer's behalf about the friends he made, the places he visited, and the items he treasured in his life.

\footnotetext{
${ }^{20}$ Tomlinson, 727. "He and his collection shared a protective anonymity."

${ }^{21}$ Freer to DePuy, 17 August 1916. Freer Gallery Archives.
} 
Freer's particular collecting style and aesthetic visions influenced how he designed his home in Detroit. Such focus on achieving the right environment for presentation, in turn, influenced the designs he chose for the building that houses his collections in Washington, D.C. Freer postulated, "It will probably be two stories, quadrangular with an inner court; no dome, no big, showy halls of any kind." He was interested in the English Tudor style for the exterior, but also considered an Italian Renaissance design, "of the most simple lines." ${ }^{22}$ He wanted the focus to be on the objects within, not the building itself.

In the last years of his life Freer consulted Platt to develop a simple and stark example of a museum. In 1909 he traveled around Europe, gathering architectural ideas. "The museum buildings thus far seen," he wrote to his good friend Hecker, "are helpful principally in showing me what not to do. ${ }^{, 23}$ He explained in greater detail:

The great aim over here seems to be pretentiousness, confusion and ugliness. The majority of the interiors are dungeon-like and mere tombs for the treasure they overshadow. If the artists whose work is so shockingly treated have any influence with the devil the souls of the architects are surely being roasted below. I would like to shovel on some fuel myself. ${ }^{24}$

In the end, Platt's inspiration for the museum style was European, after Michele Sanmicheli's designs for the Porta Nuova in Verona, built around $1540 .^{25}$ The museum building shares some features with the Italian model, such as a flat, one-story façade, but references to the Porta Nuova are not immediately apparent. Platt's design, however, does obviously pay homage to Italian Renaissance architecture in a general fashion. The resulting design, then, combines the purpose of the public museum with the allusion to

\footnotetext{
${ }^{22}$ Freer to Thayer, 12 August 1912. Freer Gallery Archives.

${ }^{23}$ Freer to Hecker, 12 June 1909. Freer Gallery Archives.

${ }^{24}$ Lawton and Merrill, 239.

${ }^{25}$ Morgan, 132.
} 
Freer as the American counterpart to the Medici. So, despite the intended American

audience, the museum reconciles two European concepts: the "harmonious arrangement of paintings" of the Renaissance princely cabinets, and the idea of the national art museum originated in "the archetypal state museum," the Louvre. ${ }^{26}$

Freer desired an edifice that would be a part of the collection, to show with the best lighting and the best environment possible the work of the artists he appreciated so much. Platt presented plans for an Italian villa-style building. ${ }^{27}$ Much in the same way Freer's home incorporated natural light with skylights and landscaping that masked the outside world, so the museum would use light from only ceiling sources and contain a courtyard that was richly landscaped and calmed the visitor with a trickling fountain.

Freer set up various halls to display the aesthetic connections or "harmonies" he perceived between oriental objects and American paintings of the time ${ }^{28}$ The largest proof of his aesthetic beliefs is in the building itself - it creates the environment for contemplation that Freer would have already had in his own home. His friend and fellow collector of Asian antiquities, Agnes Meyer, wrote that the interior would "constitute a background for the art objects and not compete with them," suggesting that simplicity was key. She wrote about the interior garden and benches "to which students could retire to meditate on the objects they had been studying." ${ }^{, 29}$ (Figure 15) Viewers also had the

\footnotetext{
${ }^{26}$ Andrew McClellan. Inventing the Louvre, Cambridge: Cambridge University Press, 1994. In his introduction, McClellan describes the Louvre as the model for national museums around the world.

${ }^{27}$ Keith N. Morgan, "The Patronage Matrix: Charles A. Platt, Architect, Charles L. Freer. Client." Winterthur Portfolio(Summer 1982): 122-134, writes about Platt's and Freer's relationship - they had known each other for many years, and Morgan points out that they shared an aesthetic philosophy. Much like Freer. "Platt was fanatical about his concern for natural illumination." Platt built a full-scale gallery model on the roof of his New York office building to experiment with lighting techniques. The resulting techniques incorporated into the museum building were considered cutting-edge.

${ }^{28}$ Carrier 2006, 102-3. "As yet there exists neither a systematic collection of museum floor plans nor a general history of museum hangings... As Andreas Beyer writes, 'There is no doubt that the sequence of works of art, their distribution, their hanging or positioning, even their illumination and wall color - in short, the manner of their display - are the essential preconditions to enable them to express something." ${ }^{29}$ Meyer, 11 .
} 
opportunity, then, to step into the bright foliage that they could only see in the Americans' paintings.

Builders set about to begin the museum's construction in the 1910s; however, the First World War and its impact on the economy and the availability of supplies put a halt to the building's progress. The ground-breaking ceremony finally took place in 1917 , and the building was finished in 1921. (Figure 16) The opening was not until two years after that, once director John Ellerton Lodge had researched and catalogued the collection. Unfortunately Freer did not live to participate in the opening - he died in 1919. 


\section{SECTION 3: \\ GRAND OPENING}

On May 1, 1923, reporters were invited to enter the Freer Gallery. This event marked the grand opening of the first art museum on the National Mall. Gertrude Richardson Brigham, present at the press opening of the Freer in May of 1923, described what she saw as she entered the new museum: "gray marble walls relieved on each side by two Chinese hangings of red velvet of the Ch'ing dynasty," and a courtyard as she climbed the steps boasting "a playing fountain" with goldfish. There were even peacocks wandering around, "[lending] a brilliant note of color," to complement Whistler's Peacock Room. She concluded, "An air of peace and quiet broods everywhere."

The next day, members of the elite class such as collectors and museum directors toured the museum. A week later, the general public finally saw what Charles Freer left as his legacy to the United States. ${ }^{2}$ Although it is difficult to conjecture exactly what everyone thought of the exhibits in 1923 , there are some published reactions to the organization of the museum and its display of Freer's aesthetic sentiments.

By the time of the opening, the Freer was no longer the only museum on the National Mall. The little gallery commemorating Freer's friendship with Whistler and their fascination with Asian art had long been preceded by the National Museum, built in 1906. The National Museum, now called the National Museum of Natural History, is a

\footnotetext{
'Gertrude Richardson Brigham, Ph.D., "Freer Collection Viewed in Private," The Washington Post 2 May 1923.

${ }^{2}$ Lawton and Lentz 33.
} 
large domed building across the way from the Smithsonian Castle (Figure 17). That museum was intended to display the Smithsonian's science and technology collection, but it also housed a wing to temporarily exhibit the Smithsonian's art holdings. In fact, Freer coordinated an exhibit there in 1912, intended as a "general survey" of his collection. ${ }^{3}$ Out of the 7,000 pieces in Freer's collection at that time, he chose 175 to show at the Smithsonian. Thirty-five works in that select grouping were American paintings. Freer's effort in 1912 served as publicity for the future museum, but also served as a reminder that Freer had given the national center its first public art museum. A friend of Freer's wrote to him in reaction to the 1912 exhibit. The reaction presaged the uncertainty some visitors would feel at the opening of the museum in 1923 :

It was a new experience, this comparison of Eastern masters with Whistler. A number of people asked me why you had shown them together or in what way you considered them alike. I told them you could best explain that, but this much could be said - both built up harmonies of line, tone and color; the art structure was similar though subjects and medium were different. ${ }^{+}$

In the seventeen years that separated the acquisition of the collection in 1906 and the opening of the museum in 1923, the art world moved on, Americans chose another President, and world powers recuperated from their involvement in the First World War. The Freer Gallery presented a time capsule from a past era and a commemoration of an artist whose work had been famous decades earlier.

The politics of Roosevelt's period that gave rise to the acceptance of Freer's gift seem to have been forgotten in the post-war era. According to the magazine Current Opinion in 1923, "The opening of the Freer Gallery in Washington is hailed not only as an artistic event of international importance, but also as a new illustration of American

\footnotetext{
${ }^{3}$ Lawton and Merrill 212.

${ }^{4}$ Dow to Freer, 15 April 1912. Freer Gallery Archives.
} 
idealism and generosity." That article concludes with a reference to a contemporaneous Christian Science Monitor article, which called Americans the heirs to Freer's benevolence. "Washington, which should lead, has lagged far behind in matters of art. It needs only a few more millionaire collectors to follow his example." While the art might not have been relevant in the 1920 s, the museum presented for some a symbol or precedent for the creation of more museums in the city center.

Friends of Freer or art connoisseurs who had read about the progress of the museum presented in newspaper reports had expectations based on their own knowledge of the collector and the collection. Visitors who attended the opening expecting to find a representation of art in America were likely surprised to find that their national collection consisted of Whistler, minor artists like Dewing, and a very large variety of panels and pottery from Japan and China.

The museum was intended for aesthetes, since what visitors would see would be the juxtaposition of ancient, foreign objects with American art from the turn of the century. Agnes Meyer stated "frankly" that the gallery "is above all things a tribute to the contemporary artist whom Mr. Freer most loved and admired, and to whom he owed, more than any other single influence, his artistic bent and education. ${ }^{.6}$ That artist was Whistler, who had encouraged Freer's interest in the arts of Asia in the first place.

According to Linda Merrill, "the unconventional assembly" of Asian and American "may have mystified casual observers," suggesting there were disparate feelings about the efficacy of Freer's presentation style in the museum, and his suggestions that the East and West are connected. She quotes one of the viewers as

\footnotetext{
${ }^{5}$ Current Opinion, LXXV, 1 July 1923.

${ }^{\circ}$ Merrill Regards 13.
} 
observing, "It is a long step from the stone statues of the early Chinese Dynasties to the art of the nineteenth century." Such a comment confirms that the message of the museum was not a universal one. "One passes from the Whistler rooms with their faint suggestion of Japanese fantasy into the deeper realms of real Japanese art," was how another responded to the arrangement, affirming that there were visitors who understood the aesthetic message. $^{7}$

Meyer writes, most importantly, about how the gallery was set up initially (Figure 18). The left side of the building presented a series of Chinese art, while the right side housed Japanese art (Figure 19). The rear of the gallery was reserved for the American art, including Whistler's work. However, Meyer writes that Whistler's Peacock Room was located at the end of the Chinese rooms, "as the apogee of the holy of holies, the ultimate offering on the altar of friendship." ${ }^{8}$ Such an observation emphasizes the subjective nature of this museum's organization. The religious references continued, with critics identifying Whistler as the "high priest" and the "deity" of the museum. ${ }^{9}$ Meyer, a confidante of Freer's, reacted so extraordinarily out of familiarity with the subject matter of the collection; she understood and shared Freer's aesthetic inclinations. There is a continual reference to the museum as a religious place where Whistler occupies the place of worshipped icon

Carol Duncan puts forth the notion that museum visitors perform a ritual process when they enter a museum. Specifically, she opines that the museum architecture instructs the visitor in such a manner that he or she immediately understands the exhibit. ${ }^{10}$

\footnotetext{
${ }^{7}$ Lawton and Merrill, 253.

${ }^{8}$ Meyer. 11.

${ }^{9}$ Merrill 253.

${ }^{10}$ Danielle Rice, "Museums: Theory, Practice, and Illusion," in Art and Its Publics, Andrew McClellan, ed. Malden: Blackwell Publishing, 2003, 83. See also Chapter One, "The Art Museum as Ritual," in Carol Duncan, Civilizing Rituals: Inside Public Art Museums. London: Routledge, 1995, 7-20.
} 
Danielle Rice disagrees with Duncan's notion that “the museum is a value-laden narrative that communicates its message effectively to all visitors." For example, the Renaissancestyle plan of connected rooms suggests that the rooms should be linked in a narrative, but the viewers who navigated that plan style in the Freer upon its opening did not necessarily perform this ritual. ${ }^{11}$ In the case of the Freer Gallery and those who attended its opening in 1923, it is dangerous to adopt Duncan's view that people entering the doors of the Freer immediately understood what they saw by walking through its rooms. While certainly people already acquainted with Freer's ways of thinking could assume connections between the American and Asian arts, to assume that everyone understood this would be to overlook the difference between elitist friends of Freer who entered with the advantage of the aesthetic perspective, and the general population who, as outsiders, assumed a narrative based on stories that surrounded the founding of the museum.

Tonelli draws on Linda Nochlin's view that American art museums inherited the museum model from Europe, and with it, the dual identity of "shrine of an elitist religion" and "utilitarian instrument for democratic education." 12 Striking that balance with a museum on the National Mall would be difficult, then, because the museum would have to represent prosperity and hold up the museum's founder as an example, but it would have to be inviting enough to draw in the American public to be instructed. In Meyer's eyes, the organization that revolved around Whistler certainly created a shrinelike memorial to the elitist beliefs of the aesthetes. The emphasis on Whistler suggests

\footnotetext{
"Rosalind E. Krauss. "Postmodernism's Museum Without Walls," in Thinking About Exhibitions, Reesa Greenberg, et al, eds. London: Routledge, 1996, 343. "The genius of the [Renaissance palace] design en filade is that each room is also insistently tied to the one before and the one after, organized through an obvious and apparent sequentiality ... a sort of narrative trajectory with each room the place of a separate chapter, but all of them articulating the unfolding of the master plot."

${ }^{12}$ Edith A, Tonelli, "The Art Museum," in The Museum: A Reference Guide. Michael Steven Shapiro, ed. New York: Greenwood Press, 1990, 33.
} 
that the purpose of the museum leaned toward the shrine to a personal relationship, and not as much toward disseminating a democratic artistic idea.

Plenty of critics wrote confused reviews of the museum, likely because they had not known Freer personally. Some did not understand the generous spacing between paintings, or why only select pieces were shown at any given time, or why there was such a limited group of American artists represented. Critic Elisabeth Luther Cary analyzed the décor of the museum and questioned the connections that Freer made between certain of his art pieces. ${ }^{13}$ She invoked Whistler to paint the walls and the dark wood of the benches and cases. Instead of connecting a Bodhisattva statue in one room to a painting in the American room, she compared it to "a Madonna of the French Gothic type." Such a comment demonstrates the European frame of reference on which Americans depended, in order to form a notion of what was art.

She marveled at the quality of Asian art, and acknowledged that it complemented Whistler's art, but said that Freer's 'theory will be questioned... casual visitors - to most of them - the collections will seem strangely assorted," especially in regard to the selection of works by Dewing. Thayer and Tryon. She then explains, probably for the reader's benefit, how their paintings could be read in connection to the Asian collection. Indeed, another commented, "the American section of the collection, so far as it is known to the public (which is very little), has been the cause of some puzzlement, owing to the fact that the names of only four men stand out in it and they in many repetitions."

\footnotetext{
${ }^{13}$ Elisabeth Luther Cary, "At the Freer Art Gallery," The New York Times 13 May 1923, SM13. An article from the previous week, "Opening of the Freer Gallery," The New York Times 6 May 1923, SM13, "The aim remained [Freer's] alone." Seventeen years after its acceptance, the museum "finds a somewhat prepared and instructed public to enjoy its offerings," a public that had read the history of the collection. It is also important to note that, seventeen years later, Americans had experienced World War I and were under a different President.

${ }^{14}$ Dana H. Carroll, The Freer Collection for the Nation. New York. 1923. Carroll wrote this booklet to enlighten the "uninformed" and "mystified" visitors who did not know how to interpret the gallery at its
} 
course, one would need to understand Freer's personal investment in the works of his friends.

Visitor Joseph Pennell's criticisms began when he saw the exterior, which he described as a "somber, prisonlike barrack... it is the more pretentious in an arty way, looking, as I have said, like a county jail or the unfinished basement of a Florentine palace - a woeful failure as an American art museum, for there is nothing American about it." The selection of Renaissance style was, of course, a curious one, but one that coordinated with the intentions to build classically-themed buildings on the National Mall.

Writer P.W. Wilson was one of many who criticized the nontraditional hanging style in the Freer Gallery, which used considerable spacing between paintings. ${ }^{16} \mathrm{He}$ compared it to the art gallery in the National Museum, where "you see merely English artists... huddled together...their portraits jostle one another, cheek by jowl... yet there comes along this American artist [Whistler] who declares that for his lightest scratch and airiest dab he must have a whole gallery to himself!" ${ }^{17}$ Although he seems to recognize the awkwardness of observing paintings in tight groupings, he seems to think that a generously spaced gallery for one artist is pretentious. In fact, Freer's preference for wellspaced paintings would have come directly from Whistler. ${ }^{18}$ Again, Freer incorporated

\footnotetext{
opening.

${ }^{15}$ Joseph Pennell, "Greatest Collection of Whistlers: Charles Freer of Detroit, and His Gift to the Nation," The New York Times 6 May 1923. His criticism of the museum extends to a criticism of Freer. Pennell writes caustically about not being allowed to see the collection at Freer's home.

${ }^{16}$ Germano Celant, "A Visual Machine: Art Installation and Its Modern Archetypes," in Thinking About Exhibitions, Reesa Greenberg, et al, eds. London: Routledge, 1996, 375. Celant writes about the incorporation of blank space in galleries, saying that in the nineteenth century the custom was to have paintings "grouped indiscriminately ... the room seems papered by a wall of paintings. The lack of space between individual artworks thus seems to indicate an interest in merging one element with another." ${ }^{17}$ P.W. Wilson, "Freer Art for Freer Galleries: Showing How a Layman May Look at Wee Whistlers on Walls Wide Enough for Michael Angelo." The New York Times 24 June 1923, SM7.

${ }^{18}$ Kenneth John Myers, Mr. Whistler's Gallery: Pictures at an 1884 Exhibition. Washington, D.C.:

Smithsonian Institution, 2003, 5. He notes that Whistler experimented with exhibition environments,
} 
into his museum what he had learned from Whistler, prompting Meyer to describe the resulting building as "a memorial to the great friendship which existed between these two men, a memorial such as no painter and but few other human beings have ever been given." ${ }^{19}$ By memorializing his friend Whistler, Freer memorializes himself as well. Freer's intent was to create an environment that elevated American art to a high status and to create an institution that established Asian art as "art" in the Western sense. For the members of the elitist circle of aesthetes, Freer's intent made sense because it was a concept with which they were intimately familiar. However, the plan to execute the aesthete's philosophy in a national museum faltered because the philosophy was not accessible to the general public in the 1920 s; without press interpretation, the general public would not have understood that they were to see this art as Freer saw it.

eventually hanging his paintings in a single row instead of in the traditional grouping method.

${ }^{19}$ Meyer quoted in Conn 2000, 171 . 


\section{CONCLUSION}

The Freer Gallery today sits "tiny and jewel-like next to the vast museum structures" that surround it (Figure 20). ${ }^{3}$ The year that he died, Freer changed his collections rule; only the American collection had to remain as he had left it. His personal ties to his American artist friends could thus be preserved. However, the Asian collection, therefore, has been greatly expanded in recent decades. Merrill comments, "the founder's intended tribute to Whistler has been obscured by the enormous growth in the Asian collections since Freer's bequest. ${ }^{32}$ The updates in the Freer collection coincided with the continuing growth of the city center. The years that followed the opening of the Freer Gallery brought more development to the beautification efforts on the National Mall. The forested area from the Capitol Building to the Washington Monument gave way to a cleared path between the two landmarks, flanked now by landscaping.

Despite its position as a national place for learning, the Freer Gallery was unsuccessful as public enterprise because the display methods used did not act in a didactic way but were merely an introductory area for elitists. To be truly educated by the collection, one would have to interact with it the way that Freer did in his home - by seeing the two types of work together, not separated into rooms labeled by country. The palpable elitism that the first visitors to the Freer perceived continued to keep people

\footnotetext{
${ }^{1}$ Curry 17.

'Merrill Regards 9.
} 
away over subsequent decades. Historian Nathaniel Burt in the 1970s was critical of the museum for showing the collection "not object by object but section by section to be viewed by those worthy of appreciating it."”

From 1988 to 1993, no one could enter the Freer Gallery because the Smithsonian closed it for renovation. In the nearly five years it remained closed to everyone except scholars who made appointments, the Freer's display cases and lighting system were updated and the gallery expanded underground, to connect to the Arthur M. Sackler museum of modern Asian art, built in the 1980s (Figure 21). In a further attempt to shed its dusty image, the Freer Gallery became part of a museum that shows rotating contemporary art shows

The year 2006 marked the centennial anniversary of the Smithsonian's acquisition of the Charles Lang Freer art collection. While today the Freer collection is regarded as an integral and natural part of the Smithsonian Institution, the Freer's significant position on the National Mall is largely overlooked. As the Smithsonian's first art museum, the Freer Gallery embodies certain social and political beliefs held by Freer himself and his friends. Other social and political beliefs that came into play were those of Theodore Roosevelt, who was President when the Freer collection became part of the nation's art holdings.

In December of 2006, former Freer Gallery Director Milo Beach published an article in the Wall Street Journal addressing the status of the gallery as a worthy educational device for contemporary visitors. ${ }^{4}$ Beach's goal was to relate the gallery or museum, as it is now more popularly known, to the rest of the National Mall and to the

\footnotetext{
${ }^{3}$ Burt 267-8.

"Milo Beach "A Century On. Freer's Collection Goes More Mainstream" The Wall Street Journal 14 Dec 2006 D6.
} 
world of Asian art as a whole. He explains Freer's background and explains how the museum has changed over the decades that it has been open. Beach wrote, "The gallery, unable to participate in major international exhibitions, became known as a scholarly retreat." Curiously, he explains the steps the Smithsonian took to get around Freer's original vision: the Smithsonian appreciates the collection, but they must be able to update it somehow. In order to manipulate the original vision, and in order to keep the Freer alive in terms of visitor numbers, they built an entirely new museum, the underground Sackler Gallery, into the building - a museum that works according to more liberal rules that can bring in new items that would presumably keep the Freer fresh and approachable.

What once was a show of artworks that seemed to stand alone, lately the focus has been on who collected them, how, and why - perhaps defeating Freer's intent to remain anonymous, but contributing to the understanding of a public now so far removed from the collection that it would otherwise not make sense. The curators now have to explain why the museum is the way it is. It does not speak for itself with any unified statement. That some contemporary displays in the Freer focus on explaining him and his collecting ideals, and the rest of the museum focuses on building its academically revered collection of Asian art, further underscore the temporary value of the museum's original intent one that is now very far removed from the contemporary public's understanding, and what has led the museum to reinvent itself to find relevance with the help of the Sackler Gallery. 


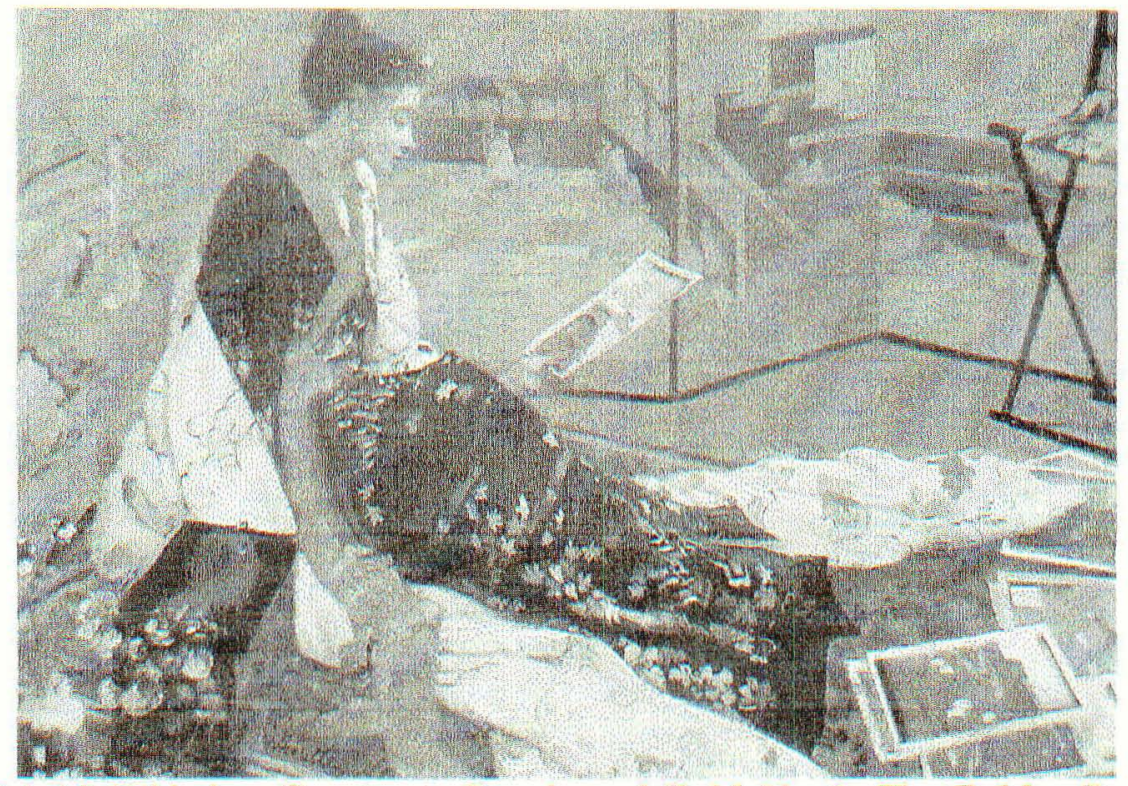

Figure 1. J.A.M. Whistler, Caprice in Purple and Gold, No. 2: The Golden Screen, 1864.

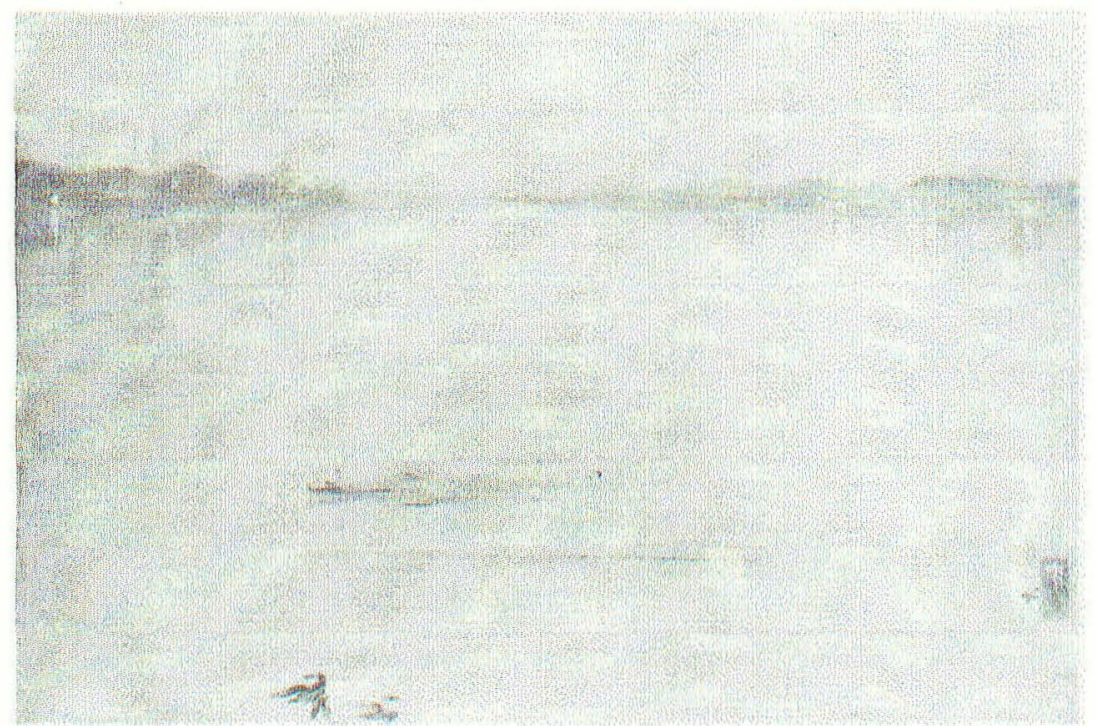

Figure 2. J.A.M. Whistler, Nocturne in Blue and Silver: Cremorne Lights, 1872. 


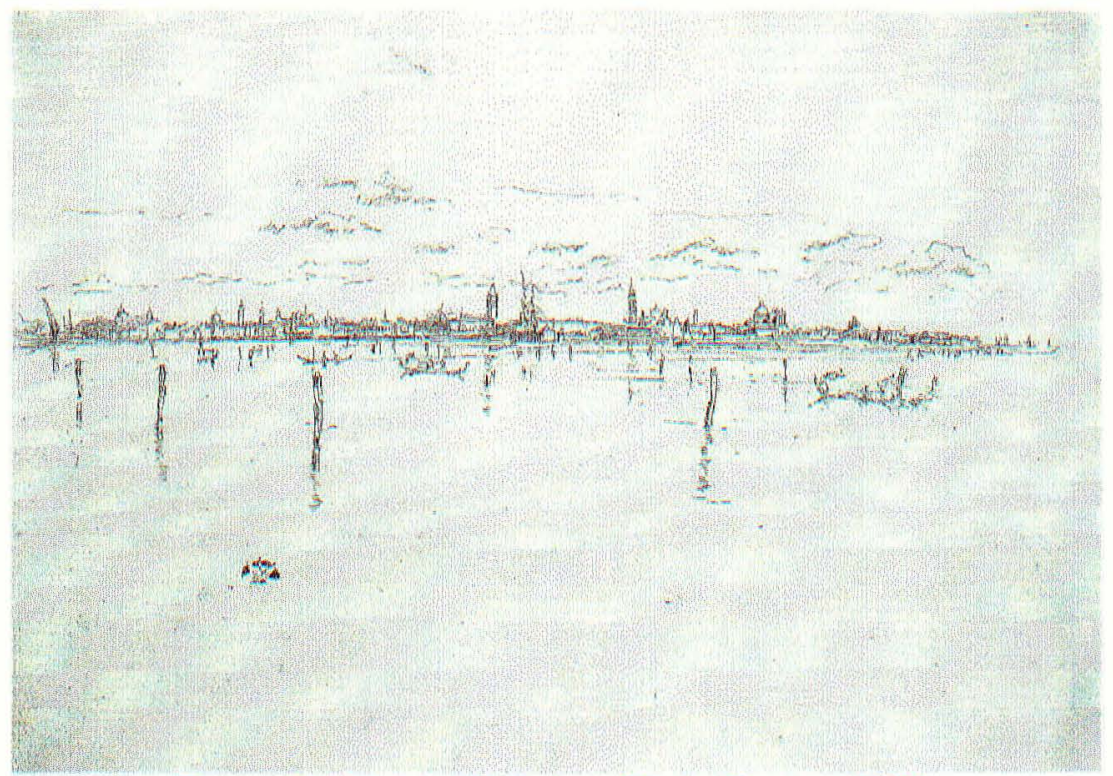

Figure 3. J.A.M. Whistler, Little Venice, 1879.

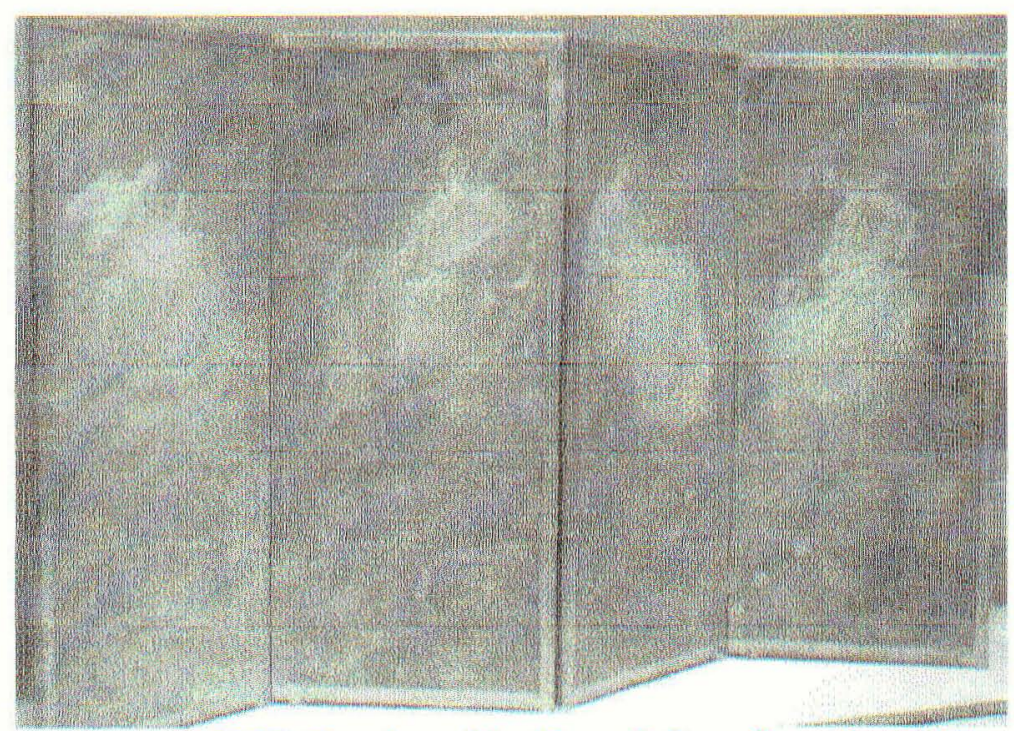

Figure 4. T.W. Dewing, The Four Sylvan Sounds, 1897 


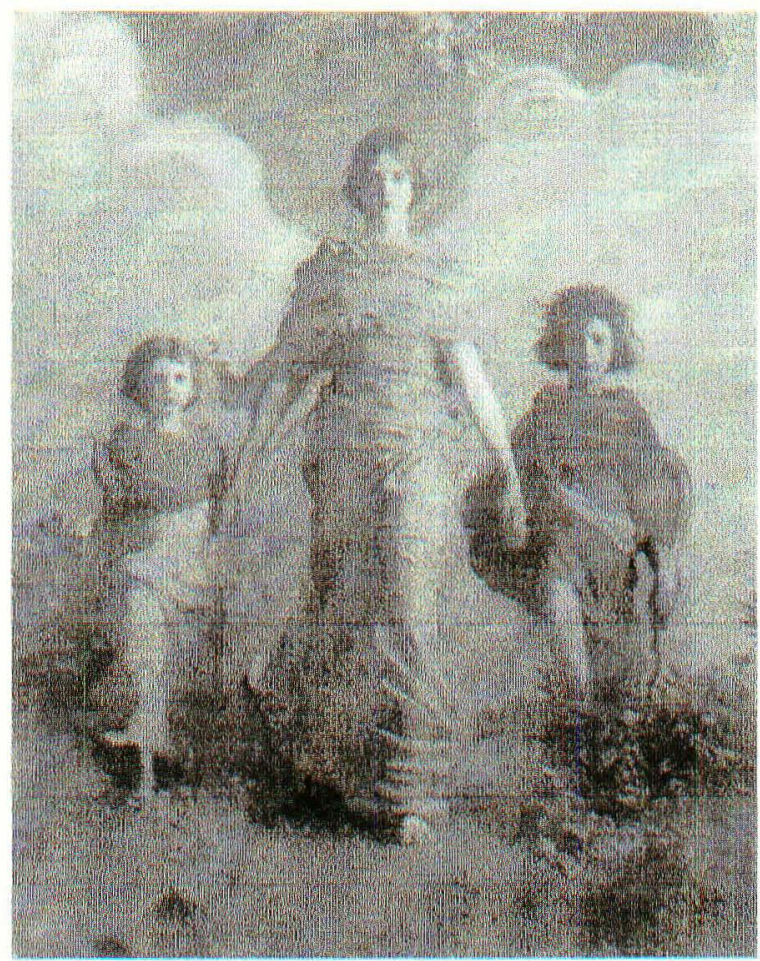

Figure 5. A.H. Thayer, A Virgin, 1893.

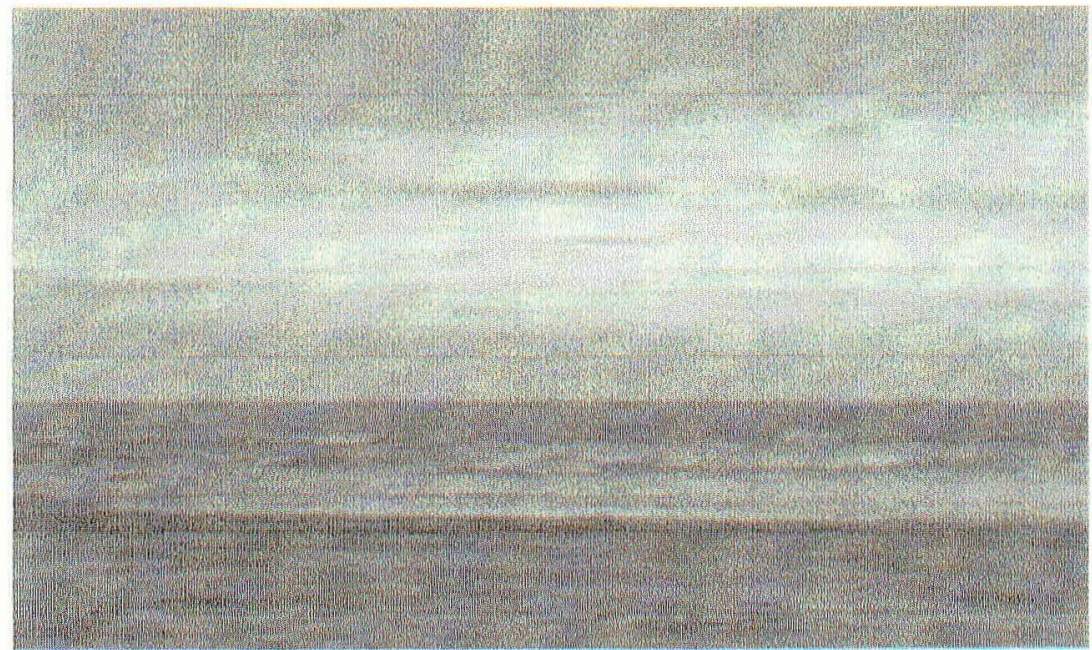

Figure 6. D.W. Tryon, The Sea: Evening, 1907. 


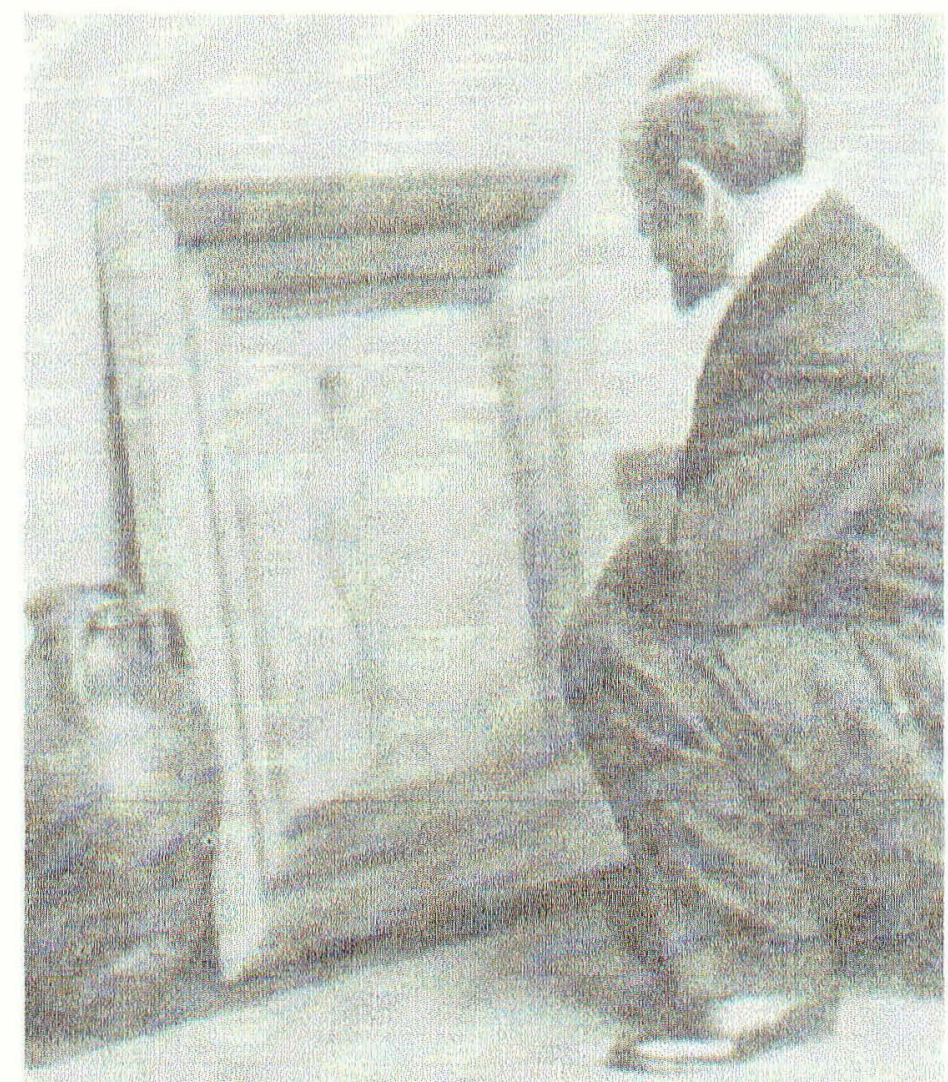

Figure 7. Freer comparing Whistler's Venus Rising and glazed pot, 1909. 


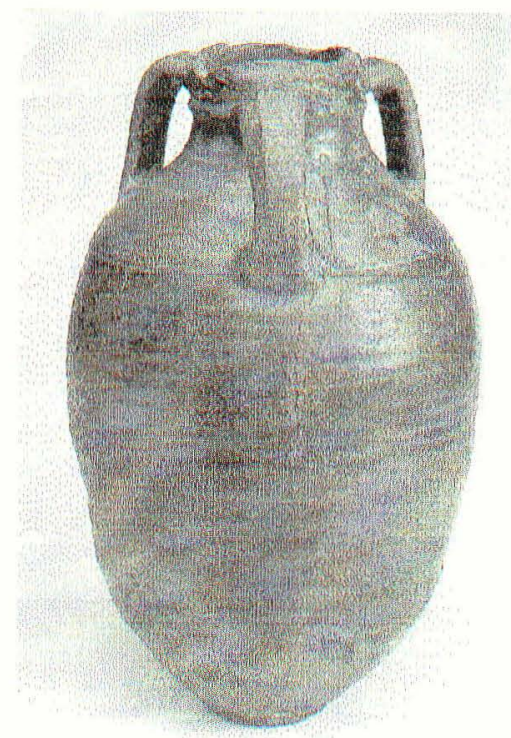

Figure 8 . Syrian jar, ca, $16^{\text {th }}$ century, Freer Gallery of Art.

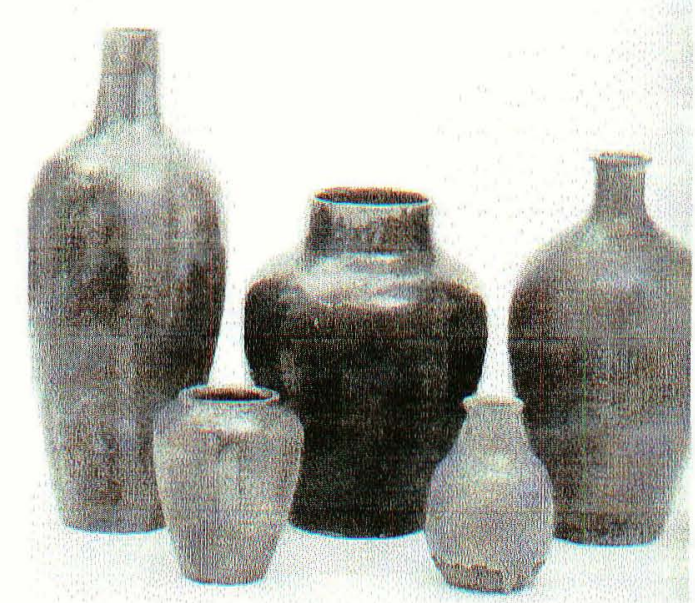

Figure 9. Examples of Pewabic pottery, early $20^{\text {th }}$ century. 


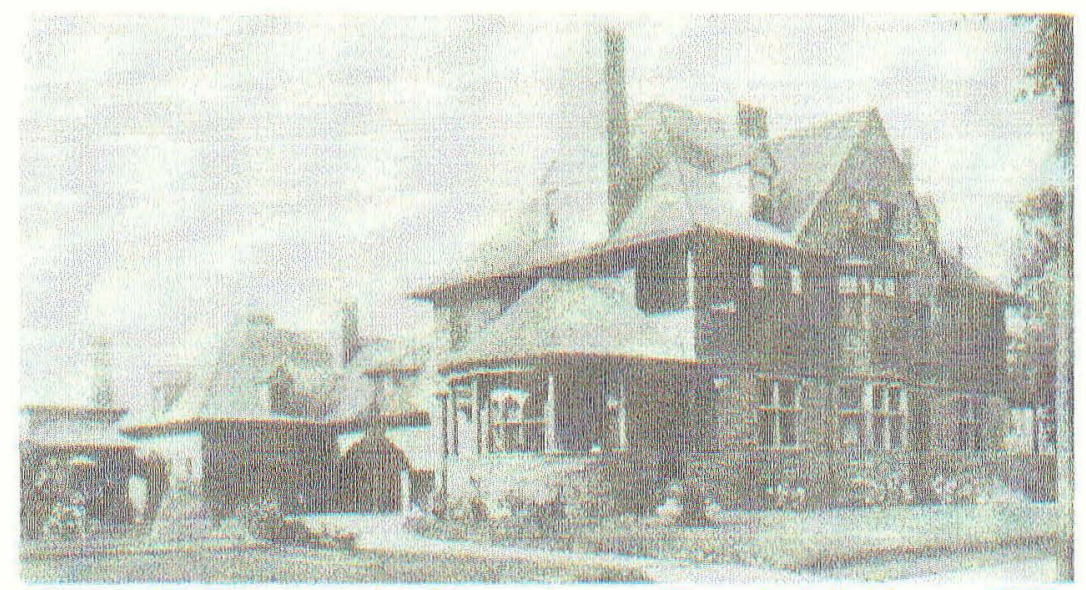

Figure 10. Photograph of Freer house, Detroit, Michigan, 1892.

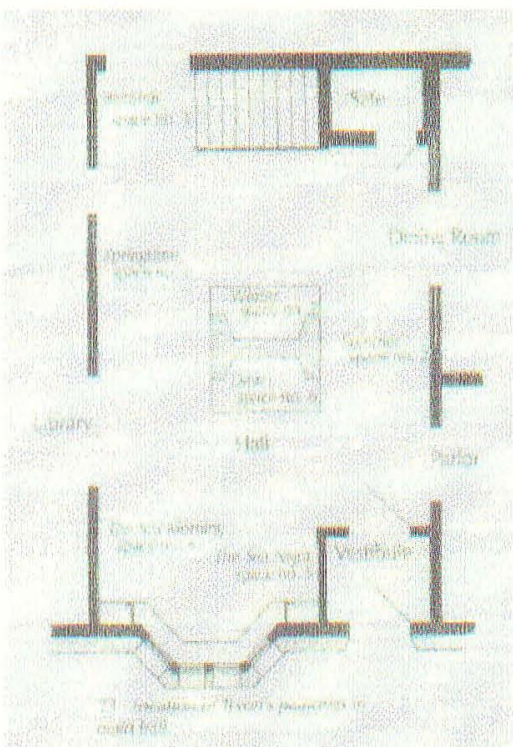

Figure 11. Room hung with paintings of the seasons, 1892. 


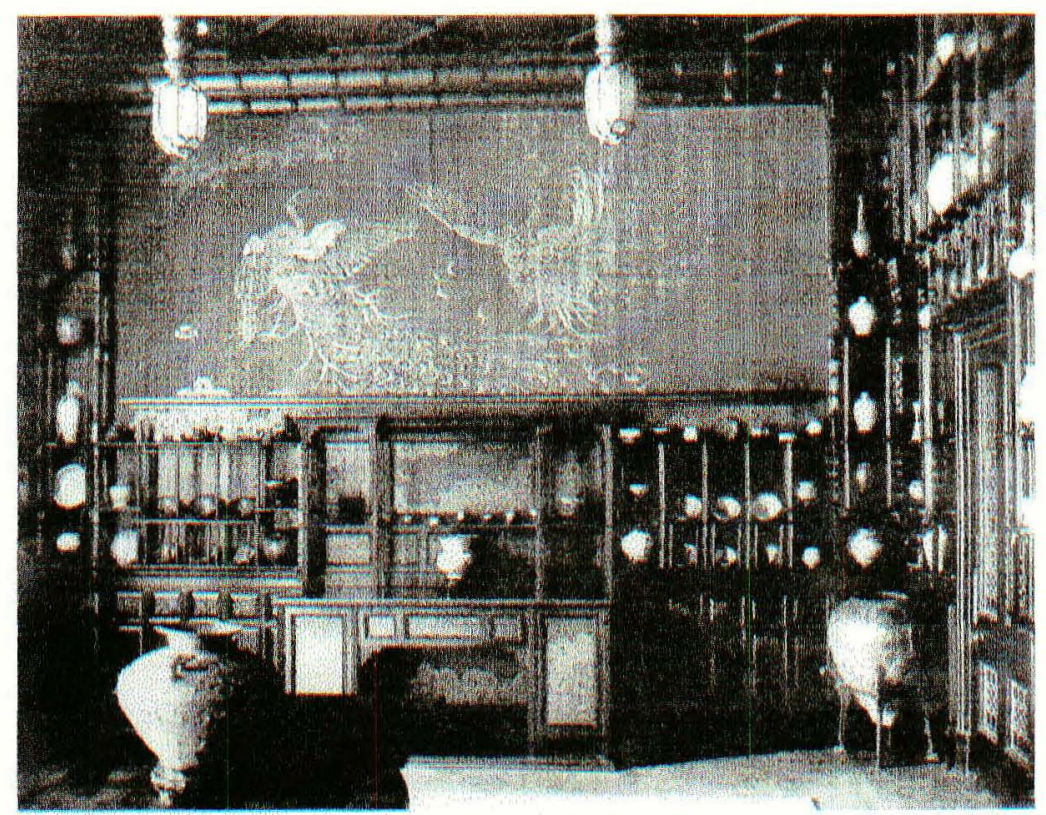

Figure 12. Peacock Room installed on Freer property, 1906

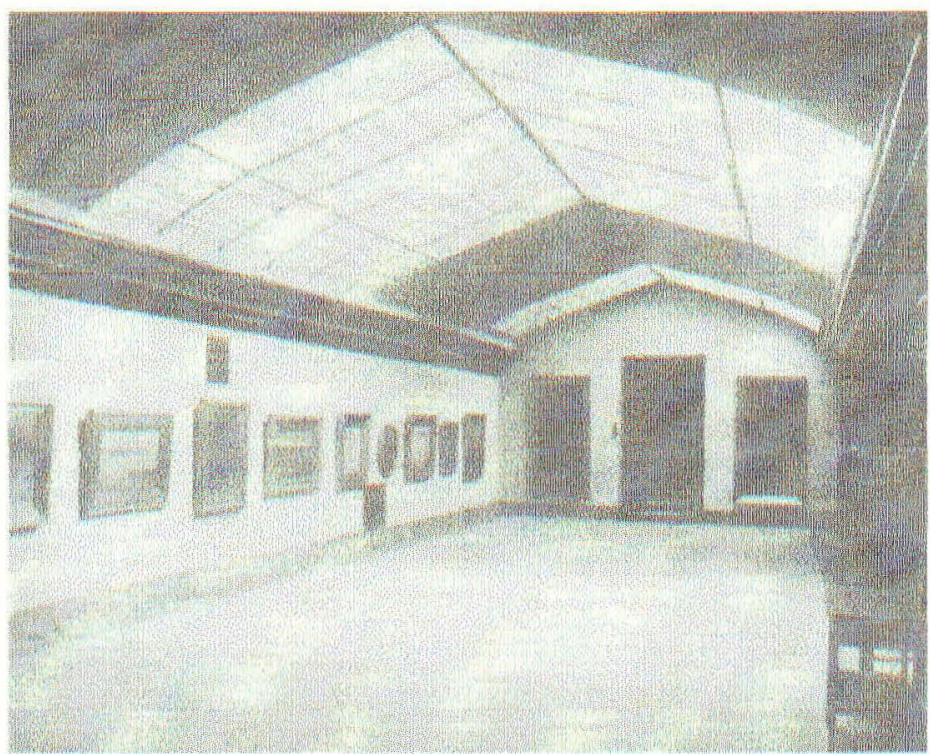

Figure 13. Gallery space, Freer house, 1904 expansion. 


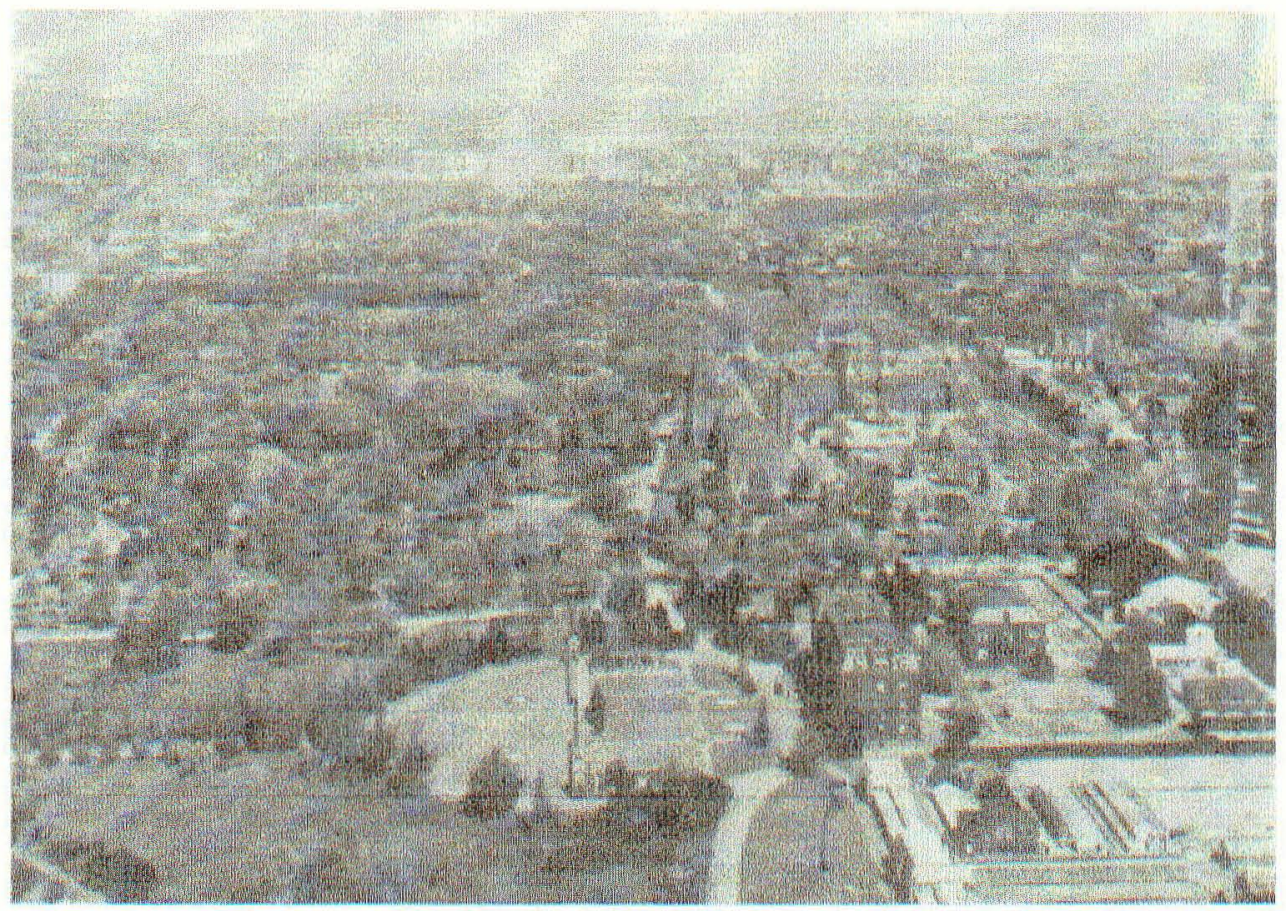

Figure 14. National Mall, Washington, D.C., 1901. 


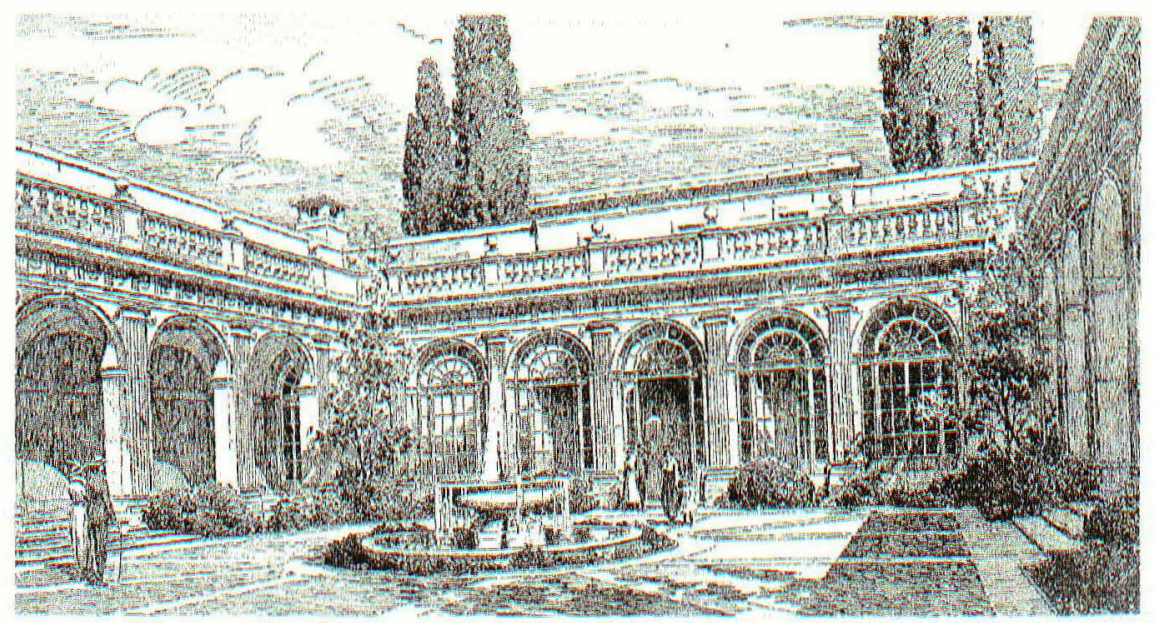

Figure 15. Courtyard of the Freer Gallery of Art, 1923

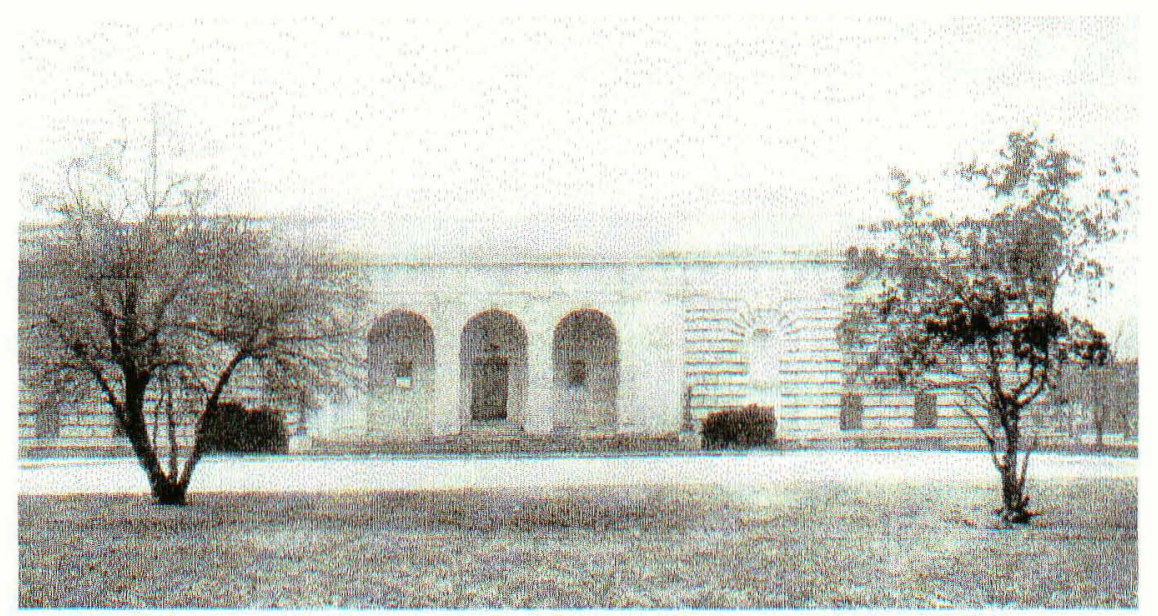

Figure 16. Photograph of Freer Gallery of Art, 1923. 


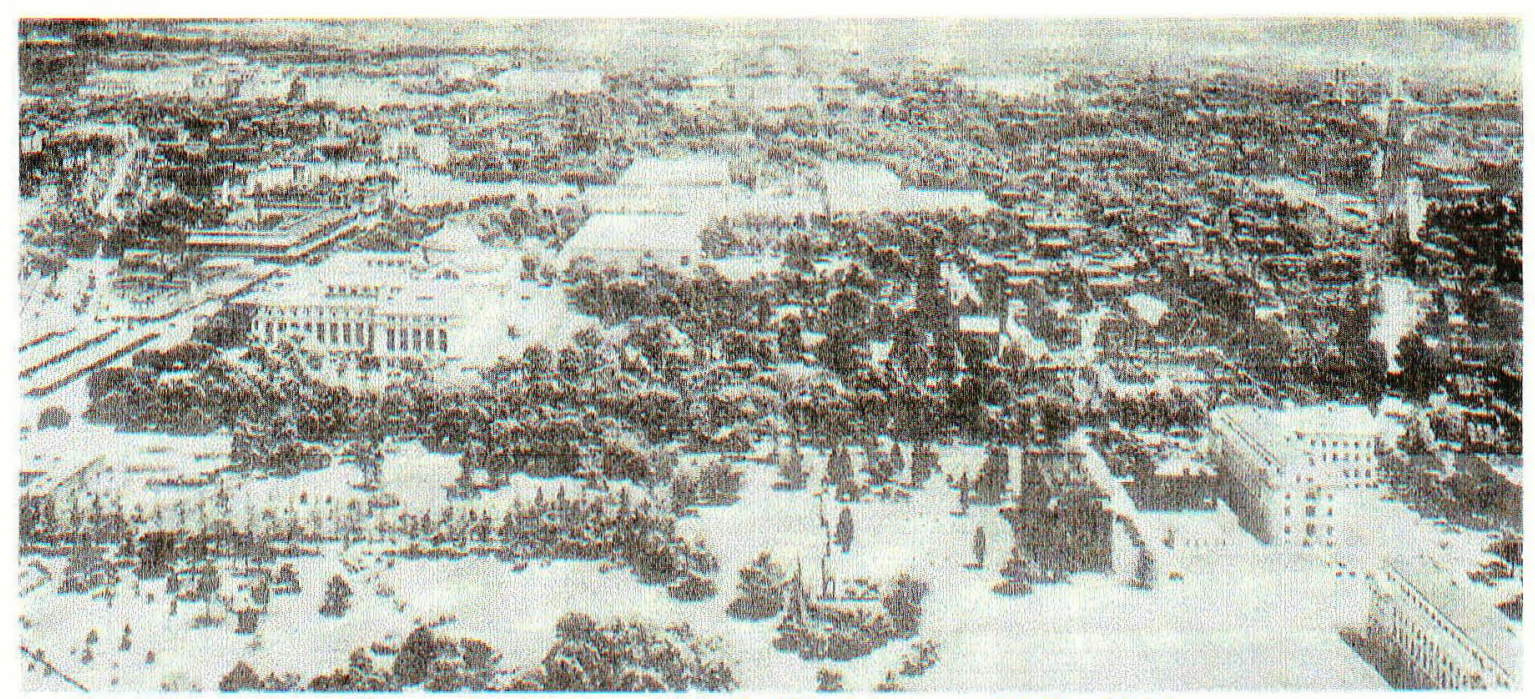

Figure 17. National Mall, Washington, D.C., 1915. 


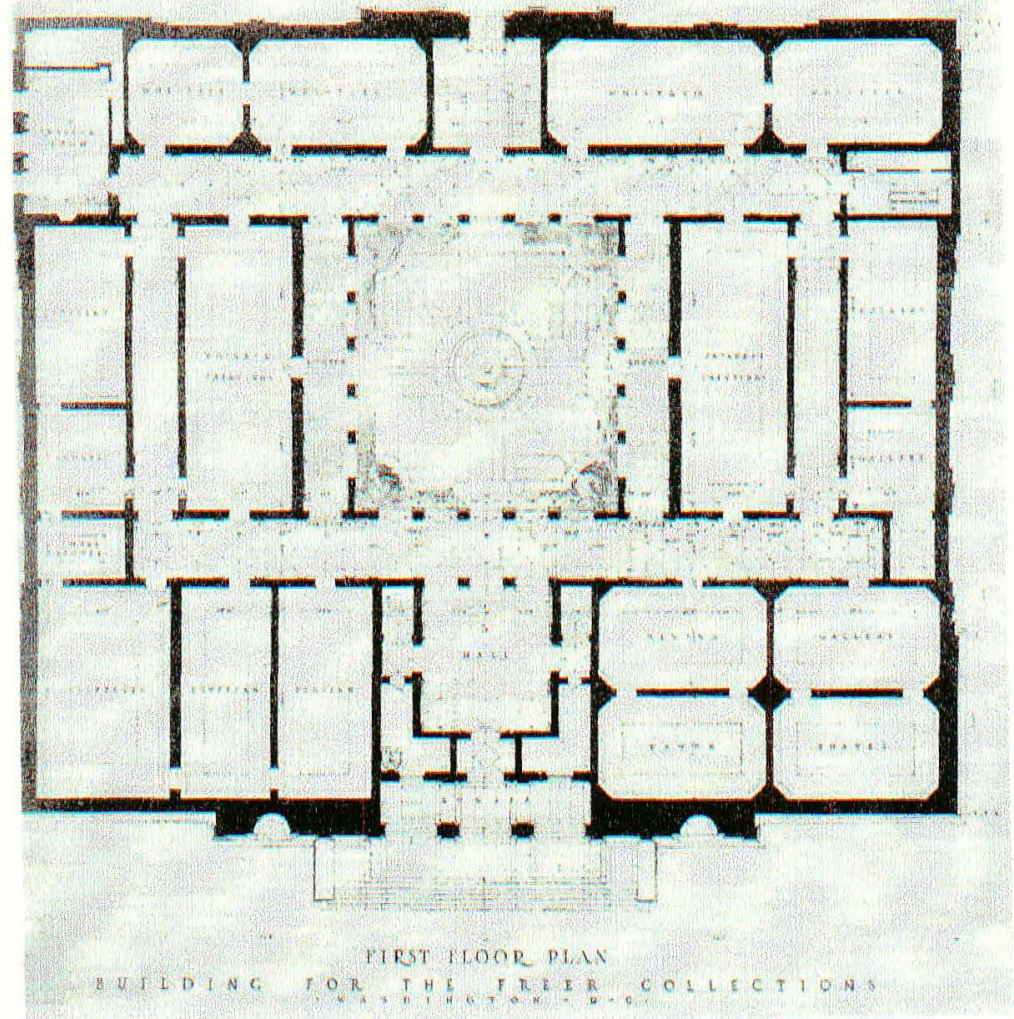

Figure 18. Floor plan, Freer Gallery of Art, 1916.

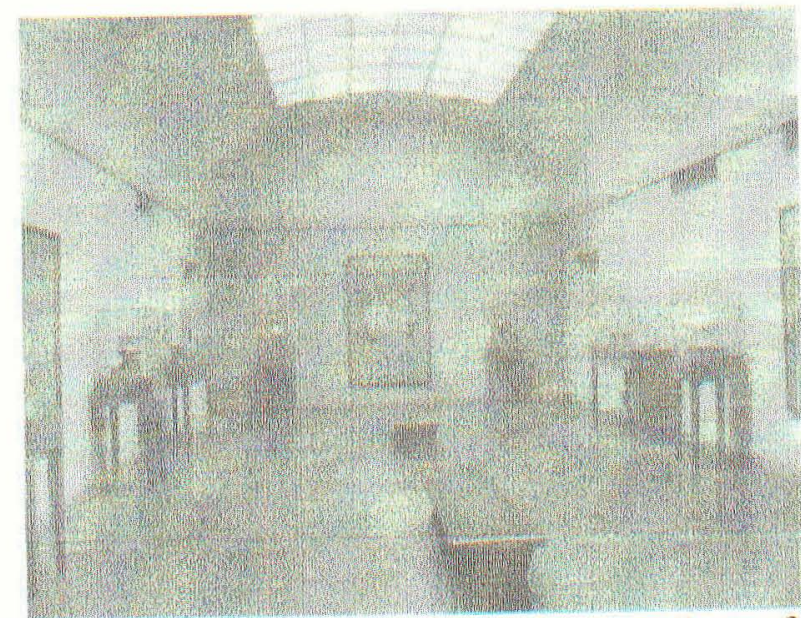

Figure 19. Photograph of gallery space, Freer Gallery of Art, 1925. 


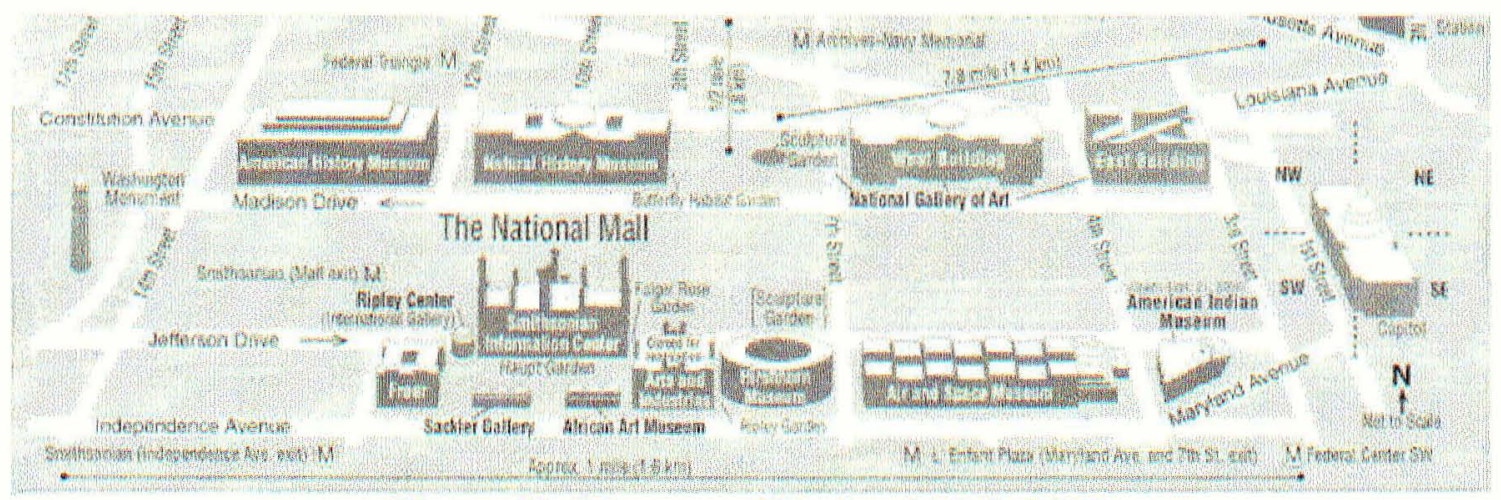

Figure 20. Diagram of National Mall, 2005

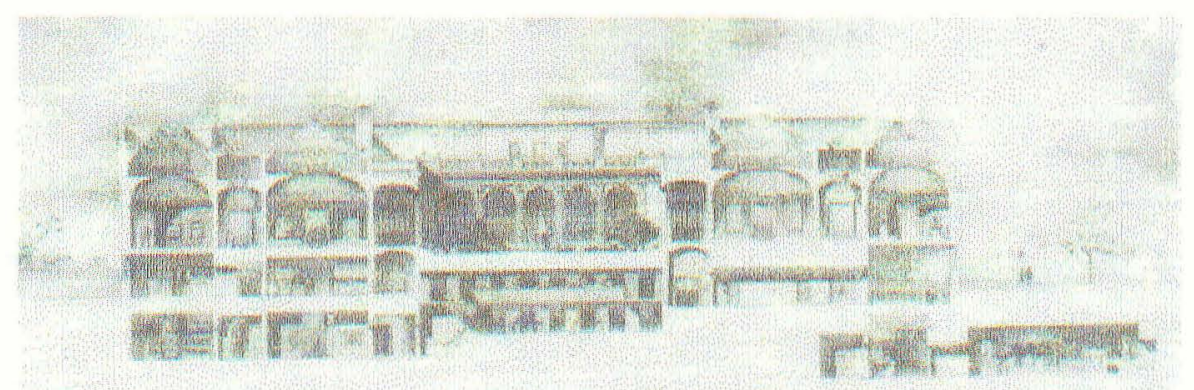

Figure 21. Elevation of renovated Freer Gallery of Art, 1990. 


\section{REFERENCES}

\section{Books}

Anderson, Ronald, and Anne Koval. James McNeill Whistler: Beyond the Myth. New York: Carroll \& Graf, 1994.

Burt, Nathaniel. Palaces for the People: A Social History of the American Art Museum. Boston: Little, Brown and Company, 1977.

Carrier, David. Introduction to England and Its Aesthetes: Biography and Taste. Essays by John Ruskin, Walter Pater and Adrian Stokes. Amsterdam: G + B Arts International, 1997.

Carroll, Dana H. The Freer Collection for the Nation. New York, 1923.

Carrier, David. Museum Skepticism: A History of the Display of Art in Public Galleries. Durham, N.C.: Duke University Press, 2006.

Chisolm, Lawrence W. Fenollosa: The Far East and American Culture. New Haven, Conn.: Yale University Press, 1963.

Collin, Richard H. Theodore Roosevelt, Culture, Diplomacy, and Expansion: A New View of American Imperialism. Baton Rouge: Louisiana State University Press, 1985.

Conn, Steven. Museums and American Intellectual Life, 1876-1926. Chicago: The University of Chicago Press, 1998.

Curry, David Park. James McNeill Whistler at the Freer Gallery of Art. Washington, D.C.: Smithsonian Institution, 1984.

Duncan, Carol. Civilizing Rituals: Inside Public Art Museums. Re-Visions: Critical Studies in the History and Theory of Art. London: Routledge, 1995.

Dyer, Thomas G. Theodore Roosevelt and the Idea of Race. Baton Rouge: Louisiana State University Press, 1980. 
Gatewood, Jr., Willard B. Theodore Roosevelt and the Art of Controversy: Episodes of the White House Years. Baton Rouge: Louisiana State University Press, 1970.

Gere, Charlotte, and Marina Vaizey. Great Women Collectors. London: Philip Wilson Publishers Limited, 1999.

Gould, Lewis L. The Presidency of Theodore Roosevelt. Lawrence: University Press of Kansas, 1991.

Greenberg, Reesa, and Bruce W. Ferguson and Sandy Nairne, eds. Thinking About Exhibitions. London: Routledge, 2000.

Gunter, Ann C. A Collector's Journey: Charles Lang Freer and Egypt. Washington, D.C.: Smithsonian Institution, 2002.

Gutheim, Frederick, and Antoinette J. Lee. Worthy of the Nation: Washington, DC, from L'Enfant to that National Capital Planning Commission. 2d ed. Baltimore: The Johns Hopkins University Press, 2006.

Hemingway, Andrew, and William Vaughan, eds. Art in Bourgeois Society, 1790-1850. Cambridge: Cambridge University Press, 1998.

Hilderbrand, Robert C. Power and the People: Executive Management of Public Opinion in Foreign Affairs, 1897-1921. Chapel Hill: The University of North Carolina Press, 1981.

Hosley, William. The Japan Idea: Art and Life in Victorian America. Hartford: Wadsworth Atheneum, 1990.

Juergens, George. News from the White House: The Presidential-Press Relationship in the Progressive Era. Chicago: The University of Chicago Press, 1981.

Lambourne, Lionel. Japonisme: Cultural Crossings between Japan and the West. London: Phaidon Press, 2005.

Lawton, Thomas and Thomas W. Lentz. Beyond the Legacy: Anniversary Acquisitions for the Freer Gallery of Art and the Arthur M. Sackler Gallery. Washington, D.C.: Smithsonian Institution, 1998.

Lawton, Thomas and Linda Merrill. Freer: A Legacy of Art. Washington, D.C.: Smithsonian Institution, 1993.

Longstreth, Richard, ed. The Mall in Washington, 1791-1991. Studies in the History of Art. Washington, D.C.: National Gallery of Art, 1991. 
McClellan, Andrew, ed. Art and Its Publics: Museum Studies at the Millennium. New Interventions in Art History. Malden, Mass.: Blackwell Publishing Limited, 2003.

McLanathan, Richard. Art in America: A Brief History. 2d ed. San Diego: Harcourt Brace Jovanovich, 1994.

Meech, Julia, and Gabriel P. Weisberg. Japonisme Comes to America: The Japanese Impact on the Graphic Arts, 1876-1925. New York: Harry N. Abrams, Inc., Publishers, 1990.

Merrill, Linda. An Ideal Country: Paintings by Dwight William Tryon in the Freer Gallery of Art. Washington, D.C.: Smithsonian Institution, 1990.

Merrill, Linda. The Peacock Room: A Cultural Biography. Washington, D.C.: Freer Gallery of Art, 1998.

Merrill, Linda, ed. With Kindest Regards: The Correspondence of Charles Lang Freer and James McNeill Whistler, 1890-1903. Washington, D.C.: Smithsonian Institution, 1995.

Meyer, Agnes. Charles Lang Freer and His Gallery. Washington, D.C.: Freer Gallery of Art, 1970.

Muensterberger, Werner. Collecting: An Unruly Passion. Psychological Perspectives. Princeton: Princeton University Press, 1994. Reprint, San Diego: Harcourt Brace \& Company, 1995.

Myers, Kenneth John. Mr. Whistler's Gallery: Pictures at an 1884 Exhibition.

Washington, D.C.: Smithsonian Institution, 2003.

Ono, Ayako. Japonisme in Britain: Whistler, Menpes, Henry, Hornel, and nineteenthcentury Japan. London: RoutledgeCurzon, 2003.

Pearce, Susan M. Museums, Objects, and Collections: A Cultural Study. Washington, D.C.: Smithsonian Institution Press, 1993.

Preziosi, Donald, ed. The Art of Art History: A Critical Anthology. Oxford History of Art. Oxford: Oxford University Press, 1998.

Preziosi, Donald, and Claire Farago, eds. Grasping the World: The Idea of the Museum. Aldershot, Hants, England: Ashgate Publishing Limited, 2004.

Reps, John W. Monumental Washington: The Planning and Development of the Capital Center. Princeton: Princeton University Press, 1967.

Said, Edward W. Orientalism. New York: Random House, Inc., 1979. 
Shapiro, Michael Steven, ed. The Museum: The Reference Guide. Westport: Greenwood Press, 1990.

Slotkin, Richard. Lost Battalions: The Great War and the Crisis of American Nationality. New York: Henry Holt and Company, 2005.

Weisberg, Gabriel P., ed. Collecting in the Gilded Age: Art Patronage in Pittsburgh, 1890-1910. Pittsburgh: Frick Art \& Historical Center, 1997.

Whitford, Frank. Japanese Prints and Western Painters. New York: Macmillan Publishing Co., Inc., 1977.

\section{Journals}

Brown Goode, G. "On the Classification of Museums." Science, New Series 3.57 (Jan 31, 1896): 154-161.

Brunk, Thomas W. "The House that Freer Built." Dichotomy 3 (Spring 1981): 5-53.

Brunk, Thomas W. "The Charles L. Freer Residence: The Original Freer Gallery of Art." Dichotomy 12 (Fall 1999): 5-151.

Chen, Constance J.S. "Transnational Orientals: Scholars of Art, Nationalist Discourses, and the Question of Intellectual Authority." Journal of Asian American Studies 9.3 (Oct 2006): 215-242.

Conn, Steven. "Where is the East? Asian Objects in American Museums, from Nathan Dunn to Charles Freer." Winterthur Portfolio 35.2/3 (Summer 2000): 157-173.

Fahlman, Betsy. "Wilson Eyre: The Charles Lang Freer House." Winterthur Portfolio 15.3 (Autumn 1980): 257-270.

Morgan, Keith N. "The Patronage Matrix: Charles A. Platt, Architect, Charles L. Freer, Client." Winterthur Portfolio 17.2/3 (Summer 1982): 121-134.

Pyne, Kathleen. "Portrait of a Collector as an Agnostic: Charles Lang Freer and Connoisseurship." The Art Bulletin 78.1 (Mar 1996): 75-97.

\section{Newspapers and Magazines}

"Likes Freer's Gift: President Urges Acceptance of Fine Art Collection." The Washington Post 26 Dec 1905, 1.

"Opening of the Freer Gallery." The New York Times 6 May 1923, SM13. 
Beach, Milo C. "A Century On, Freer's Collections Go More Mainstream.” Wall Street Journal 14 December 2006, D6.

Luther Cary, Elisabeth. "At the Freer Art Gallery." The New York Times 13 May 1923, SM13.

Pennell, Joseph. "Greatest Collection of Whistlers: Charles Freer of Detroit, and His Gift to the Nation." The New York Times 6 May 1923, 3, 14.

Richardson Brigham, Gertrude. "Freer Collection Viewed in Private." The Washington Post 2 May 1923, 8.

Wilson, P.W. "Freer Art for Freer Galleries." The New York Times 24 June 1923, SM7.

\section{Theses and Dissertations}

Chen, Constance Jing Shue. "From Passion to Discipline: East Asian Art and the Culture of Modernity in the United States, 1876-1945." Ph.D. diss., University of California, Los Angeles, 2000.

Clark, Henry Nichols Blake. "Charles Lang Freer: Patron of American Art in the Gilded Era." M.A. thesis, University of Delaware, 1975.

Glazer, Lee. "'A Modern Instance:' Thomas Dewing and Aesthetic Vision at the Turn of the Century." Ph.D. diss., University of Pennsylvania, 1996.

Kloner, Jay Martin. "The Influence of Japanese Prints on Edouard Manet and Paul Gauguin.” Ph.D. diss., Columbia University, 1968.

Levine, Stephen L. "Race, Culture, and Art: Theodore Roosevelt and the Nationalist Aesthetic." Ph.D. diss., Kent State University, 2001.

Mendelson, Valerie. "A Citadel Behind Walls? The House of the Amateur in Late Nineteenth-Century France." Ph.D. diss., The City University of New York, 2004.

Tomlinson, Helen Nebeker. "Charles Lang Freer: Pioneer Collector of Oriental Art." Ph.D. diss., Case Western Reserve University, 1979.

\section{Records}

Charles Lang Freer Correspondence, 1876, 1886-1920. Freer Gallery of Art. Smithsonian Institution. 


\title{
CURRICULUM VITAE
}

\author{
Patricia L. Guardiola \\ 300 South Evergreen Road \\ Louisville, KY 40243-2010 \\ Home: (502) 254-9732 \\ E-mail: plguard82@hotmail.com
}

\section{Education:}

M.A. August 2007 University of Louisville, Art History

B.A. May 2004 Bellarmine University, Communication (Summa Cum Laude)

Professional Experience:

$2007-2008$

Fulbright Student Grantee to the Principality of Andorra Teaching English as a Second Language

$2006-2007$

Teaching Assistant to Dr. Linda Gigante ARTH 250: Survey of Ancient to Medieval Art ARTH 351/551: Greek Art \& Architecture University of Louisville Hite Art Institute

2005 - 2006 Teaching Assistant to Dr. Christopher Fulton ARTH 342/542: Mexican Art \& Architecture ARTH 203: Introduction to Art University of Louisville Hite Art Institute

2005 - 2006 Cataloguing Assistant to Dr. Linda Gigante Roman Funerary Collection Speed Art Museum, Louisville

Summer 2005

Research Intern

Smithsonian Institute for the Interpretation and Representation of Latino Cultures

Smithsonian Center for Latino Initiatives

Washington, D.C. 
Spring 2005

Research Assistant to Dr. John Ferré

University of Louisville Department of Communication

Awards:

2007-2008 Fulbright Teaching Assistantship

J. William Fulbright Foreign Scholarship Board

$2005-2007 \quad$ Frederick and Elizabeth Cressman Scholarship

University of Louisville Hite Art Institute

Summer $2006 \quad$ Hite Art Institute Travel Grant

Museum research in Mexico City, Mexico

\section{Professional Service:}

$2006-2007$

Secretary and Treasurer

Aegis, Association of Fine Arts Graduate Students

University of Louisville

Summer 2006 Gallery Interpreter

Sam Gilliam: A Retrospective

Speed Art Museum, Louisville

Oct. 2005, Oct. 2006 Student Assistant, Art Auction

Louisville Visual Arts Association

\section{Professional Affiliations:}

Golden Key International Honours Society

Southeastern College Art Conference

\section{Languages Read/Spoken:}

Reading, Writing, Speaking Spanish, Catalan

Basic Reading Italian, French 